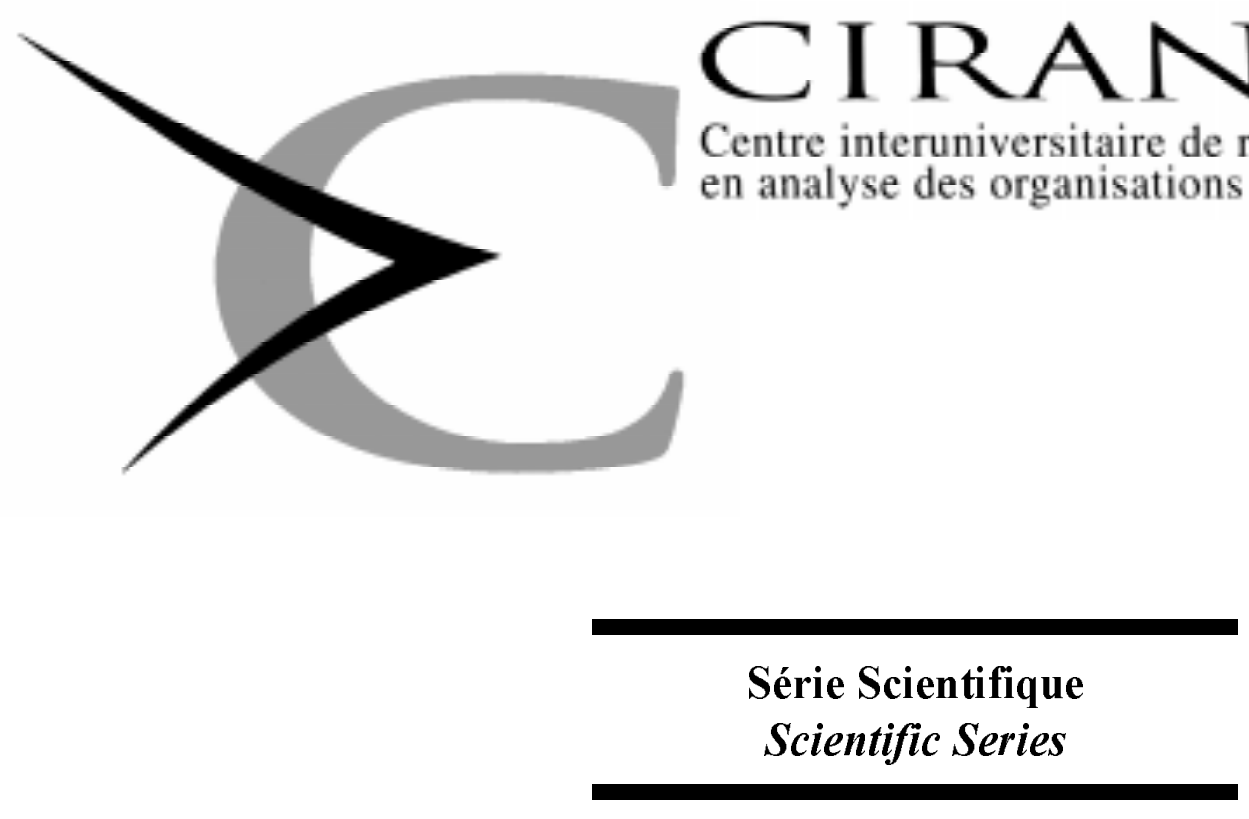

$96 s-22$

Should We Abolish Chapter 11?

Evidence from Canada

Timothy C.G. Fisher,

Jocelyn Martel 


\section{CIRANO}

Le CIRANO est une corporation privée à but non lucratif constituée en vertu de la Loi des compagnies du Québec. Le financement de son infrastructure et de ses activités de recherche provient des cotisations de ses organisations-membres, d'une subvention d'infrastructure du ministère de l'Industrie, du Commerce, de la Science et de la Technologie, de même que des subventions et mandats obtenus par ses équipes de recherche. La Série Scientifique est la réalisation d'une des missions que s'est données le CIRANO, soit de développer l'analyse scientifique des organisations et des comportements stratégiques.

CIRANO is a private non-profit organization incorporated under the Québec Companies Act. Its infrastructure and research activities are funded through fees paid by member organizations, an infrastructure grant from the Ministère de l'Industrie, du Commerce, de la Science et de la Technologie, and grants and research mandates obtained by its research teams. The Scientific Series fulfils one of the missions of CIRANO: to develop the scientific analysis of organizations and strategic behaviour.

\section{Les organ isations-partenaires / The Partner Organizations}

-École des Hautes Études Commerciales.

-École Polytechnique.

-McGill University.

-Université de Montréal.

-Université du Québec à Montréal.

-Université Laval.

-MEQ.

-MICST.

-Avenor.

-Banque Nationale du Canada

-Bell Québec.

-Fédération des caisses populaires de Montréal et de l'Ouest-du-Québec.

-Hydro-Québec.

-La Caisse de dépôt et de placement du Québec.

- Raymond, Chabot, Martin, Paré

-Société d'électrolyse et de chimie Alcan Ltée.

-Téléglobe Canada.

-Ville de Montréal.

Ce document est publié dans l'intention de rendre accessibles les résultats préliminaires de la recherche effectuée au CIRANO, afin de susciter des échanges et des suggestions. Les idées et les opinions émises sont sous l'unique responsabilité des auteurs, et ne représentent pas nécessairement les positions du CIRANO ou de ses partenaires.

This paper presents preliminary research carried out at CIRANO and aims to encourage discussion and comment. The observations and viewpoints expressed are the sole responsibility of the authors. They do not necessarily represent positions of CIRANO or its partners.

\section{ISSN 1198-8177}




\title{
Should We Abolish Chapter 11? Evidence from Canada*
}

\author{
Timothy C.G. Fisher ', Jocelyn Martel
}

\section{Résumé / Abstract}

\begin{abstract}
Au cours de la dernière décemie, le Chapitre 11 du U.S. Bankruptcy Code a été l'objet de critiques importantes de la part de juristes et d'économistes américains. Récemment, un certain nombre de ces juristes ont soulevé la possibilité de réformer le Chapitre 11 sur la base du système canadien en matière de réorganisation commerciale. Le but du présent article est de démontrer que l'expérience canadiemne en matière de réorganisation commerciale est révélatrice sur les réformes potentielles à apporter au Chapitre 11. Les domées canadiemnes montrent clairement que les taux d'acceptation, de confirmation et de succès des propositions commerciales sont très élevés. De plus, la probabilité de survie des firmes canadiennes est de dix fois supérieure à celle des firmes américaines. Les données canadiennes permettent également de rejeter l'affirmation selon laquelle l'échec de la procédure de réorganisation origine de son utilisation par les petites entreprises. Qui plus est, la procédure canadienne offre une solution rapide aux entreprises en difficultés financières et un rendement espéré aux créanciers supérieur par rapport à la procédure de liquidation. Sur la base de notre évaluation comparative des deux systèmes d'insolvabilité, nous suggérons la révision plutôt que 1'abolition du Chapitre 11
\end{abstract}

Over the last decade, Chapter 11 has been the brunt of serious criticism. Some American jurists arguing in favor of revising Chapter 11 have raised the possibility that the Canadian reorganization system might be a good alternative to the existing U.S. system. This article argues that there are friutful lessons to be learned from the Canadian experience with court-supervised reorganization. Canadian experience shows that acceptance, confirmation, and consummation rates of proposals are very high. Moreover, firms reorganizing in Canada are almost ten times more likely to survive reorganization than their American counterparts. Furthermore, Canadian data yield no support for the claim that problems with bankruptcy law result from an over-abundance of small firms in reorganization. The analysis also shows that the Canaidan reorganization procedure offers a very rapid solution to financial distress and that creditors gain, in expected value terms, from reorganization over

\footnotetext{
"Correspondence adress: Jocelyn Martel, CIRANO, 2020, University Street, 25th floor, Montréal, Qc, Canada H3A 2A5 Tel: (514) 985-4000 Fax: (514) 985-4039 e-mail: martelj@cirano.umontreal.ca We would like to thank the Bankruptcy Branch of Industry Canada for making available the data used in the study and Henri Massüe-Monat for his legal expertise. Errors and omissions are the responsibility of the authors

${ }^{+}$Wilfrid Laurier University

${ }^{\ddagger}$ Université de Cergy-Pontoise, THEMA and CIRANO
} 
liquidation. Based on our evaluation of the relative performance of both systems, we argue that Chapter 11 be revised rather than repealed.

Mots Clés : $\quad$ Faillite, Réorganisation, Chapitre 11, Loi sur la faillite

Keywords : $\quad$ Bankruptcy, Reorganization, Chapter 11, Bankruptcy Act

JEL : G33 


\section{Introduction}

Over the last decade, bankruptcy laws in many industrial countries have been the object of fierce attacks by jurists and economists. At the same time, many countries have revised their bankruptcy laws. France and the United Kingdom adopted new insolvency/bankruptcy laws in 1985 and 1986, respectively, while in Canada, a series of amendments to the Bankruptcy Act came into effect in December $1992 .^{1}$

In the U.S., the very existence of Chapter 11 of the Bankruptcy Code is being seriously challenged. A number of authors have suggested replacing Chapter 11 with a market-oriented valuation mechanism. ${ }^{2}$ It is argued that a market-oriented scheme is the best method for dividing the reorganization pie while ensuring that firms come out of reorganization with the appropriate capital structure. The main drawback with this type of scheme is that it involves substantial revisions to existing bankruptcy and corporate laws as well as a fundamental change in the design of bankruptcy laws. In addition, it involves the creation of new financial markets for rights in reorganized firms and all the information and coordination problems that go along with it. ${ }^{3}$ Others have proposed substantial revisions to the way Chapter 11 deals with insolvency. ${ }^{4}$ Without suggesting the abolition of Chapter 11, they propose

\footnotetext{
${ }^{1}$ J. Beardsley, The New French Bankruptcy Statute, 19 International Lawyer (1985); D. Webb, An Economic Evaluation of Insolvency Procedures in the United Kingdom: Does the 1986 Insolvency Act Satisfy the Creditors' Bargain, 43 Oxford Economic Papers (1991); T. Fisher \& J. Martel, Will the Bankruptcy Reforms Work? An Empirical Analysis of Financial Reorganization in Canada, XX Canadian Public Policy (1994); J. Martel, More on the Impact of Bankruptcy Reform in Canada. Working Paper 94s-17, CIRANO (1994).

${ }^{2}$ P. Aghion, O. Hart and J. Moore, The Economics of Bankruptcy Reform, 8 J. of Law, Economics and Organization (1992); L. Bebchuk, A New Approach to Corporate Reorganizations, 101 Harvard Law Review (1988); M. Bradley and M. Rosenzweig, The Untenable Case for Chapter 11, 101 Yale Law Journal (1992); R. Rasmussen, Debtor's Choice: A Menu Approach to Corporate Bankruptcy, 71 Texas Law Review (1992); M. Roe, Bankruptcy and Debt: A New Model for Corporate Reorganization, 83 Columbia Law Review (1983).

${ }^{3}$ D. Baird, Revisiting Auctions in Chapter 11, 36 Journal of Law \& Economics (1993).

${ }^{4}$ D. Baird, The Uneasy Case for Corporate Reorganization, 15 J. of Legal Studies (1986); D. Baird, A World Without Bankruptcy, 50 Law and Contemporary Problems (1987); T. Eisenberg, Baseline Problems in Assessing Chapter 11, 43 U. of Toronto Law Journal (1993); L. LoPucki, The Trouble with Chapter 11, Wisconsin Law Review (1993); T. Eisenberg and S. Tagashira, Should we Abolish Chapter 11? Evidence from Japan, 23 J. of Legal Studies (1994); T. Jackson, The Logic and Limits of Bankruptcy: Cambridge, Mass.: Harvard University Press, 1986.
} 
that bankruptcy laws should respect existing rights and honor negotiated agreements since not doing so invites inefficient strategic behavior.

Attacks on Chapter 11 are based on a number of stylized facts that highlight the negative aspects of a court-supervised reorganization procedure. The literature contains six fundamental criticisms of Chapter 11.

1. The probability of confirmation in Chapter 11 is very low. Two recent studies show that the confirmation rate in Chapter 11 is less than 20 percent, suggesting that Chapter 11 is better at promoting failure rather than rescuing firms in financial difficulty. ${ }^{5}$

2. Small businesses filing for Chapter 11 typically end up in liquidation. In a sense, this is related to the first point since Flynn (1989) estimates that the probability of confirmation is about five times higher for cases with more than $\$ 1$ million in assets compared to cases with less than $\$ 1$ million in assets. Since roughly 80 percent of Chapter 11 cases filed since 1979 involve assets under $\$ 1$ million, some authors suggest that Chapter 11 should be oriented towards the rescue of large firms and that small and medium size firms should be routed to Chapter $7 .^{6}$

3. The probability of emerging from a Chapter 11 reorganization as an ongoing business is very low. ${ }^{7}$ Recent data show that firms have a less than 10 percent chance of surviving Chapter 11 proceedings.

4. Unsecured creditors usually have a weak bargaining position relative to the debtor. Chapter 11 gives the debtor an exclusivity period to propose a reorganization plan of 120 days after filing for bankruptcy plus a 60-day period for its approval by creditors. This exclusivity period is often extended by the court, which makes it very difficult

\footnotetext{
${ }^{5}$ E. Flynn, Statistical Analysis of Chapter 11, Bankruptcy Division of the Administrative Office of the U.S. Court (1989); S. Jensen-Conklin, Do Confirmed Chapter 11 Plans Consummate? The Results of a Study and Analysis of the Law, 97 Commercial Law Journal (1992); L. LoPucki, The Debtor in Full Control - Systems Failure Under Chapter 11 of the Bankruptcy Code?, 57 American Bankruptcy Law Journal (1983).

${ }^{6}$ G. Bermant, A. Lombard and E. Wiggin, A Day in the Life: The Federal Judicial Center's 1988-1989 Bankruptcy Court Time Study, 65 American Bankruptcy Law Journal (1991); T. Eisenberg and S. Tagashira, supra note 4; T. Eisenberg, supra note 4.

${ }^{7} \mathrm{~S}$. Jensen-Conklin, supra note 5; D. Baird, supra note 3.
} 
for creditors to propose their own plans or amendments to the original plan. ${ }^{8}$

5. The absolute priority rule is systematically violated in Chapter $11 .^{9}$ This is also related to the last point since creditors may be willing to forego part of their claims to speed-up the procedures.

6. Chapter 11 is time-consuming, litigious, and costly. ${ }^{10}$

Rather than ask whether a market-oriented system is more appropriate than a legally-oriented system, we examine the more modest question of whether the existing U.S. Bankruptcy Code can be improved, and if so, how. Some American jurists have raised the possibility that the Canadian system may well be a good alternative to the existing U.S. system. ${ }^{11}$ The empirical work of Martel and Fisher \& Martel clearly shows that the Canadian reorganization process does not suffer many of the same pitfalls as Chapter $11 .^{12}$ Moreover, comparing the U.S. and Canadian reorganization procedures, LoPucki \& Triantis conclude:

${ }^{8}$ L. LoPucki and W. Withford, Bargaining over Equity's Share in the Bankruptcy Reorganization of Large, Publicly Held Companies, 139 U. of Pennsylvania Law Review (1990); L. Weiss, Bankruptcy Resolution: Direct Costs and Violation of Priority of Claims, 27 Journal of Financial Economics (1990).

${ }^{9}$ K. Daigle and M. Maloney, Residual Claims in Bankruptcy: An Agency Theory Explanation, 37 Journal of Law and Economics (1994); A. Eberhart, W. Moore and R. Roenfeldt, Security Pricing and Deviations from the Absolute Priority Rule in Bankruptcy Proceedings, 45 Journal of Finance (1990); J. Franks and W. Torous, An Empirical Investigation of U.S. Firms in Reorganization, 44 Journal of Finance (1989); and L. Weiss, supra note 8 .

${ }^{10}$ E. Flynn, supra note 5; S. Jensen-Conklin, supra note 5; M. White, Bankruptcy Liquidation and Reorganization, in Handbook of Modern Finance, ed. D. Logue, Boston, Warren, Gorham \& Lamont, Chapter 35 (1984).

${ }^{11} \mathrm{G}$. Triantis, The Interplay of Liquidation and Reorganization in the Bankruptcy Systems of Canada and the U.S.: The Role of Screens, Gatekeepers and Guillotines, 16 International Review of Law \& Economics (1996).

${ }^{12}$ T. Fisher \& J. Martel, supra note 1; T. Fisher \& J. Martel, Financial Reorganization in Canada, 2 Canadian Business Economics (1994); T. Fisher \& J. Martel, The Creditors' Financial Reorganization Decision: New Evidence from Canadian Data, 11 J. of Law, Economics and Organization (1995); J. Martel, supra note 1; J. Martel, Commercial Bankruptcy and Financial Reorganization in Canada, Working Paper 94c-2, CIRANO (1994). 
"... it should be possible to determine the relative merits of the two approaches through an empirical comparison of the outcomes of reorganization in the two countries."

This quote precisely captures the aim of the present paper. In particular, we use data on the reorganization process in Canada and compare it to data from U.S. studies to see what lessons for Chapter 11 can be learned from the Canadian experience with financial reorganization.

A comparative study of this type raises two issues: first, whether the process of reorganization in Canada is sufficiently similar to Chapter 11 to justify the exercise, and second, whether firms reorganizing in Canada are comparable to firms using Chapter 11 in the U.S. Other comparative studies, like Eisenberg and Tagashira (1994), which use Japanese firms undergoing reorganization as a yardstick for the Chapter 11 procedure, are, of course, subject to the same concerns.

On the first count, obviously there are differences between Chapter 11 and the Canadian reorganization procedure. ${ }^{13}$ However, as pointed out by LoPucki \& Triantis (1994), although both systems differ in their doctrine, there are important similarities in their functioning. ${ }^{14}$ Both require a plan to be filed by debtors, approved by creditors, and confirmed by the court. Key aspects of any reorganization plan under either system are the proposed payment to creditors and the structure of the payments. Lastly, firms emerge as ongoing entities from Chapter 11 or the Canadian reorganization procedure only if they meet all the provisions of their reorganization plans. Given these similarities, it is natural to consider the implications of the Canadian experience for potential reform to Chapter 11. In addition, we will argue below that the differences that do exist between the two systems highlight precisely the reforms needed for Chapter 11. It should be noted that the data used in this study are from the period prior to the 1992 amendments to the Canadian Bankruptcy Act. The revisions, which came into effect in December 1992, made the Canadian bankruptcy system more similar to the U.S. Bankruptcy Code. ${ }^{15}$ Thus, future comparative studies of the U.S. and

\footnotetext{
${ }^{13}$ L. Lopucki \& G. Triantis, supra note 14; G. Triantis, supra note 11.

${ }^{14}$ L. Lopucki \& G. Triantis, A Systems Approach to Comparing U.S. and Canadian Reorganization of Financially Distressed Companies, Harvard International Law Journal, 35 (1994). According to the authors, "Although the lawmakers in the two countries set out to create very different systems, the systems were bound to converge over time toward a steady state in which the parts would form a functional whole."

${ }^{15}$ The idea of having a "Canadian" Chapter 11 is not new. In 1984, the newly appointed
} 
Canada will be based on even more similar reorganization procedures.

Whether the Canadian firms examined in this paper are similar to firms passing through Chapter 11 in the U.S. is difficult to say, primarily because there is no data set on U.S. firms that is comparable to the data we examine here. Excepting Flynn (1989), U.S. empirical studies typically have two features in common: a small number of observations and nonrandom samples. ${ }^{16}$ In contrast, the data that we examine here comprise a relatively large number of observations that are randomly chosen from the population of all reorganizing firms under the Canadian Bankruptcy Act. Thus, while we are confident the Canadian data present an accurate portrait of reorganization, the same cannot be said for the U.S. data used for comparison.

The paper is organized as follows. The next section describes the Canadian reorganization procedure. Section 3 briefly describes how the data were collected and section 4 discusses the main characteristics of the firms present in the data. Section 5 contains our analysis of the relative performance of the court-supervised reorganization procedure in Canada and the U.S. Section 6 uses the analysis of the previous section to make some tentative recommendations for reforming Chapter 11. Section 7 contains a few concluding remarks.

\section{Canadian Reorganization Procedure}

In Canada, insolvency comes under federal jurisdiction and statute. In addition, there exist two distinct court-supervised reorganization procedures:

Minister of the Department of Consumer and Corporate Affairs, which was responsible for the administration of the Bankruptcy Act in Canada, stated that the government should consider introducing a new bankruptcy law similar to the U.S. Bankruptcy Code. See Mayrand. M, The Background of Canadian Bankruptcy Law, Policy Forum on Reform of the Bankruptcy Act, ed., Frank Lewis, John Deutsch Institute for the Study of Economic Policy, Queen's University, 1985.

${ }^{16}$ Casey, C.; McGee, V.; and Stickney, C. "Discriminating Between Reorganized and Liquidated Firms in Bankruptcy." 61 The Accounting Review (1986) and Franks and Torous, supra note 9 , examine only successful Chapter 11 cases, which are clearly not representative of all firms attempting reorganization. The White 1984), supra note 10 and the LoPucki (1983), supra note 5, studies are confined to specific geographical areas and, as such, their data may not be representative of all U.S. firms going through Chapter 11. The same conclusion applies to White, M. "Economics of Bankruptcy: Liquidation and Reorganization." Working Paper No. 239. New York: Solomon Brother Center for the Study of Financial Institutions, Graduate School of Business Administration, New York University (1981). 
(i) a proposal pursuant to Part III of the Bankruptcy $A c t^{17}$ and (ii) a proposal under the Companies' Creditors Arrangement Act (hereafter CCAA). ${ }^{18}$

The Insolvency Act, which applied only to businesses, was introduced in 1869 and repealed in 1880. Thus, Canada was without any insolvency legislation until 1919 when the Bankruptcy Act (hereafter BA), which was largely borrowed from the British Bankruptcy Act of 1904, was enacted. The BA was revised in 1949, offering recourse to insolvent individuals as well as to insolvent businesses. ${ }^{19}$ As mentioned above, the BA was again revised in December $1992 .^{20}$

The CCAA was enacted in 1933 to facilitate the reorganization of insolvent companies, a procedure not provided by the BA of 1919. It originally applied to all insolvent companies but an amendment in 1953 restricted its use to debtors having outstanding secured or unsecured bonds issued under a trust deed. ${ }^{21}$ Given that there exists very little to no information on firms using the CCAA, we concentrate our analysis on reorganization under the BA prior to the December 1992 amendments. $^{22}$

A proposal under the BA can only be filed by an insolvent or a bankrupt debtor. ${ }^{23}$ The reorganization process is triggered upon the filing of a proposal

\footnotetext{
${ }^{17}$ Bankruptcy Act, R.S.C. 1985, c. B-3.

${ }^{18}$ An Act to Facilitate Compromises and Arrangements Between Companies and Their Creditors, R.S.C. 1985 , c. C-36.

${ }^{19}$ For some historical background and a detailed discussion of bankruptcy and insolvency in Canada, see A. Bohémier, Faillite et Insolvabilité, Tome 1, Montréal, ed. Thémis, 1992, L. Duncan \& J. Honsberger, Bankruptcy in Canada, 3d, Ed. Toronto, Canada Law Book Company Ltd (1961) and B. Leonard, Guide to Commercial Insolvency in Canada, Butterworths, Toronto, 1988.

${ }^{20}$ An Act to Amend the Bankruptcy Act and to Amend the Income Tax in consequence thereof (Bill C-22), S.C. 1992, c. 27. Correspondence between sections of the "old" and the "new" acts are given in brackets in footnotes.

${ }^{21}$ C.C.A.A. $\S 3$.

${ }^{22}$ Although there are yet no formal records on the use of the CCAA, the authors are presently setting up an original data set on firms reorganizing under this procedure. Contrary to perception, the CCAA is used much less often than the reorganization procedure under the BA.

${ }^{23} \mathrm{BA}$. $\S 50$. An insolvent person is defined as "a person who is not bankrupt and who resides or carries on business in Canada, whose liabilities to creditors provable as claims under the BA amount to $\$ 1000$, and (a) who is for any reason unable to meet his obligations as they generally become due, (b) who has ceased paying his current obligations in the ordinary course of business as they generally become due, and (c) the aggregate of whose property is not, at a fair valuation, sufficient, or, if disposed at a fairly conducted sale under legal process, would not be sufficient to enable payments of all obligations, due and
} 
with a licensed trustee. The trustee is then responsible for supervising the proceedings, informing creditors about the financial situation of the debtor, conducting investigations into the affairs and the property of the debtor, and calling the meetings of creditors. ${ }^{24}$ Creditors of an insolvent debtor are not entitled to file a proposal but they may propose amendments to the original proposal before the proposal is finally approved. However, a proposal can be modified only with the debtor's consent.

The BA identifies two broad classes of creditors. First, there are secured creditors, which are defined as persons holding a mortgage, charge, lien or security interest against the property of the debtor. Second, there are unsecured creditors, who are persons not falling into the above category. There are two classes of unsecured creditors: (i) preferred creditors, who receive priority in the distribution of the debtor's assets, and (ii) ordinary creditors.

The filing of a proposal triggers an automatic stay of proceedings, which freezes all unsecured creditors' rights against the firm's assets. ${ }^{25}$ Secured creditors are not bound by the stay of proceedings and they may realize or deal with their security in the event of default by the debtor. ${ }^{26}$ However, their rights may be stayed by the Court, for a period of up to six months from the date of approval of the proposal, in order to give the debtor some breathing room. ${ }^{27}$ The stay of proceedings enables the debtor to continue operating under the protection of the bankruptcy court while negotiating a new arrangement with its creditors. Typically, this arrangement takes the form of repaying creditors gradually over time. The repayments may be made in cash or installments or in equity in the reorganized firm, or some combination thereof. In practice, a plan ensures the payment of secured claims in accordance with existing arrangements between the debtor and the secured creditors. Similarly, preferred claims are paid in full before anything is paid to ordinary creditors. Ordinary creditors are offered partial or sometimes full payment of their original claims. During reorganization, the original management usually remains in control of the firm. However, creditors may appoint

accruing due." A bankrupt person refers to "a person who has made an assignment or against whom a receiving order has been made or the legal status of that person." BA. $\S 2$.

${ }^{24}$ BA. $\S \S 50(5), 51(1)$ [BIA. $\left.\S \S 50(5), 51(1)\right]$.

${ }^{25}$ BA. $\S 69(1)$ [BIA. $\left.\S 69(1)\right]$.

${ }^{26}$ Since 1992, the rights of secured creditors are stayed for a 30-days period following the filing of a notice of intention to file a proposal by a debtor. BIA. $\S \S 69(1), 69(2)$.

${ }^{27}$ BA. $\S 69(2)$. 
a committee of inspectors, which stays in place for the period covered by the proposal, to supervise the activities of the debtor. ${ }^{28}$

To be accepted, a proposal requires the affirmative vote of a majority in number of unsecured creditors representing at least 75 percent in value of the proven claims of unsecured creditors voting, personally or by proxy, at the meeting. ${ }^{29}$ Secured creditors are not entitled to vote on a proposal unless their security is partially covered, in which case they may vote for the unsecured portion of their claims. ${ }^{30}$ If the proposal is rejected, the debtor is deemed to have made a voluntary assignment on the day the proposal was filed. ${ }^{31}$ If the proposal is accepted, the trustee applies to the court for confirmation. ${ }^{32}$ A proposal cannot be confirmed unless claims are paid according to the absolute priority rule, meaning preferred creditors must be paid in full before ordinary creditors receive any payment. ${ }^{33}$ All monies are payable to the trustee who is then responsible for distributing it to creditors. ${ }^{34}$ In addition, the court may refuse to confirm a proposal under any of the following circumstances: if it views that the proposal is unreasonable; if it views the proposal not to be in the interest of creditors; if the debtor has committed any offense mentioned in sections 198 to 200 of the $\mathrm{BA} ;{ }^{35}$ if any of the facts listed in sections 173 or 177 are proven against the debtor and the proposal pays less than fifty cents on the dollar on all unsecured claims). ${ }^{36}$ In the vast majority of cases, the court does not interfere with the

\footnotetext{
${ }^{28}$ BA. $\S \S 55,56$ [BIA. $\left.\S \S 55,56\right]$.

${ }^{29}$ BA. $\S 2$ (special resolution). The 1992 amendments lowered the claims criterion from 75 to $66 \frac{2}{3}$ percent. BIA. $\S 54(1)$.

${ }^{30}$ Since 1992, a debtor may include secured creditors in a proposal. Secured creditors covered by a proposal can either vote in favor of the proposal or opt out by rejecting it. BIA. $\S \S 69.1(1), 69.1(6)$. However, secured creditors not covered by the proposal may realize their security in the event of a default. BIA. $\S 69.1(5)$.

${ }^{31}$ BA. $\S 57$. Since 1992, the date of the assignment is the earliest of (i) the day on which the proposal was filed, (ii) the day on which the notice of intention, if any, was filed, and (iii) the day on which the first petition, if any, for a receiving order in respect of that insolvent person was filed. BIA. $\S 57$.

${ }^{32}$ BA. $§ 58$ [BIA. §58].

${ }^{33}$ BA. $\S 60(1)$ [BIA. $\left.\S 60(1)\right]$.

${ }^{34}$ BA. $\S 60(2)$ [BIA. $\left.\S 60(2)\right]$.

${ }^{35}$ BA. $\S 59(2)[$ [BIA. $§ 59(2)]$.

${ }^{36}$ BA. $\S 59(3)$ [BIA. $\left.\S 59(3)\right]$. Since 1992, there are two necessary other conditions for confirmation. First, the proposal must provide for the full repayment of claims for source deductions within six months from confirmation. BIA. $\S 60(1.1)$. Second, wage claims (for a maximum of $\$ 2000$ per worker) must be fully repaid upon confirmation. BIA. $\S 60(1.3)$
} 
creditors' decision. A proposal accepted by the unsecured creditors and the court is binding on all the unsecured creditors with provable claims. ${ }^{37}$ If the court refuses to confirm the proposal, the debtor is deemed to have made an assignment on the day the proposal was filed. ${ }^{38}$

An accepted proposal is defined as successful when the debtor meets all the terms of the proposal before the trustee is discharged. ${ }^{39}$ The court may annul the proposal if it feels that the proposal cannot continue without injustice or undue delay or upon an application by a creditor following default on any of the provisions of the proposal. ${ }^{40}$ Following an annulment by the court, the debtor is deemed to have made an assignment on the day of the annulment. ${ }^{41}$

\section{Data}

Each reorganization plan made under the BA is filed with one of the 15 regional bankruptcy offices of Industry Canada. The data in the present study are collected directly from plans filed by individual firms with the Montreal and Toronto offices. ${ }^{42}$ A random sample of 500 plans is taken from the approximately 1,280 commercial reorganization plans filed in the two cities during the $1977-88$ period. ${ }^{43}$ Owing to insufficient data and missing or incomplete files, the final sample has 393 files, of which 273 originated in Montreal and 120 originated in Toronto. ${ }^{44}$

\footnotetext{
${ }^{37}$ BA. $\S 62(2)$. Since 1992, a proposal is also binding on secured creditors who voted in favor of a proposal. BIA. $\S 62(2)$.

${ }^{38}$ BA. $\S 61(2)$. Since 1992, the date of assignment for a non confirmed proposal is determined in the same fashion as the date of assignment for a rejected proposal. See supra note 31 .

${ }^{39}$ The term 'successful' is used by Fisher \& Martel (1994a) and Martel (1994b), supra note 12 , though it is not defined in the $\mathrm{BA}$ and in the BIA.

${ }^{40}$ BA. $\S 63(1)$ [BIA. $\left.\S 63(1)\right]$.

${ }^{41}$ BA. $\S 63(4)$ [BIA. $\left.\S 63(4)\right]$.

${ }^{42}$ For a detailed description of the data set, see Martel (1994a), supra note 12.

${ }^{43}$ Random sampling is carried out using the Systematic Random Sampling Procedure. The sample is chosen to be representative of the regional distribution of plans filed each year over the sample period.

${ }^{44}$ Fisher and Martel (1994b), supra note 12, examine a similar data set of 338 reorganizing firms which filed at the Halifax, Montreal, Toronto, Calgary and Vancouver bankruptcy offices over the period 1978-87. The present data set has slightly more firms and includes more variables.
} 


\section{Summary Statistics}

Table 1 presents financial data on reorganizing firms. Firms attempting reorganization under the BA are clearly quite small, with average assets of $\$ 2.5$ million and average debts of $\$ 3.0$ million. ${ }^{45}$ The vast majority of firms in the sample are privately owned; there are only 10 with publicly traded shares. As might be expected with financial data, the variables are highly skewed. For example, while the mean value of assets is $\$ 2.5$ million, more than 75 percent of the firms have assets of less than $\$ 1.2$ million. A simple regression of assets against a constant and year of filing indicates that there is no statistically significant trend in firm size over the sample period. ${ }^{46}$

Obviously, firms filing for financial reorganization face severe financial problems. The mean asset/debt ratio of 58 percent indicates just how bad a position most of these firms are in. ${ }^{47}$ The secured debt/asset ratio gives an indication of the ability of reorganizing firms to attract new loans. Secured debt represents around 55 percent of the assets of reorganizing firms, indicating that there is some room for these firms to negotiate new secured loans. Secured debt represents about one-third of total debt, which is to say that firms rely heavily on secured debt. Moreover, on average, one-fifth of the total debt of reorganizing firms is owed to a single secured creditor. This suggests that individual secured creditors may have a significant amount of bargaining power over firms when it comes to renegotiating loans. On average, government debt makes up less than 5 percent of total firm debt. ${ }^{48}$ However, Fisher and Martel (1995) and Martel (1996a) find that even this small amount has a significantly negative effect on the likelihood of successful financial reorganization. ${ }^{49}$

There are around 110 creditors for each reorganizing firm, the vast majority of which are ordinary creditors. Typically, the firms have only a handful

\footnotetext{
${ }^{45}$ All dollar figures in the text are December 1993 Canadian dollars, deflated by the GDP deflator (Cansim Series Number D20556). To convert these figures to U.S. dollars, the average noon spot exchange rate in December 1993 was US $\$ 1.00=\mathrm{C} \$ 1.33$ (Cansim Series Number B3400).

${ }^{46} \mathrm{~A}$ similar regression with debts as the dependent variable yields an analogous result.

${ }^{47}$ For comparison, the mean debt-asset ratio is 16.0 (excluding 14 firms with zero assets) and the median ratio is 1.8 .

${ }^{48}$ The term 'government debt' refers to money owed to federal and provincial governments and is sometimes referred to as 'Crown debt'.

${ }^{49}$ T. Fisher \& J. Martel (1995), supra note 12; J. Martel, Signaling in Financial Reorganization, Theory and Evidence from Canada, Unpublished Manuscript, CIRANO (1999).
} 
of secured creditors. Note also that wage earners, who, roughly speaking, count as preferred creditors, are relatively rare. This is indicated by the mean value for preferred creditors which is 7 times greater than the median value.

Table 2 presents various descriptive statistics of the reorganization process. The process moves along fairly quickly at the outset; at least half the plans have been voted on by ordinary creditors within 25 days of filing. The complete reorganization process (the time from filing to the discharge of the debtor from bankruptcy by the court) takes quite a bit longer; the mean is just over three years and the median is around two-and-a-half years.

The statistics on the creditors' meeting present a very interesting picture of the process. Four plans in 10 are amended before creditors vote, so clearly negotiation takes place between the debtor and its creditors. Around 30 creditors usually show up for the creditors meeting, but this represents only about one-third of the creditors that are eligible to vote on the plan. Clearly, the majority of ordinary creditors are either willing to forgo their rights to participate in the reorganization decision of debtors that owe them money or they rely on larger and better informed creditors to defend their interests at the meeting.

The direct costs of reorganization are measured by the administration costs, which have a mean value of $\$ 46,300$ and a median of $\$ 20,000$. The largest component of administration costs are the fees paid to the bankruptcy trustee, which typically account for around 70 percent of administration costs. Using median values, it appears that administration costs are relatively small compared to total debt or repayments to creditors. However, recall that administration costs are given priority over all other claims and that these reorganizing firms are severely financially constrained. Therefore, it is possible that the relatively small administration costs may have a significantly negative impact on the likelihood of successful reorganization, similar to the effect of government claims.

\section{Analysis}

The primary aim of our work is to compare the ability of the U.S. and Canadian reorganization procedures to screen viable from non-viable firms. We use the following criteria to accomplish the task:

1. acceptance and confirmation of proposals 
2. consummation of proposals

3. occurrence of filtering failure

4. expected payment and the best-interests test

5. administrative costs

6. length of the reorganization process

7. violation of absolute priority

Martel (1996a) models reorganization as a multi-stage game. ${ }^{50}$ At the first stage of the game, the proposal is submitted to creditors for approval. Following approval and confirmation by the court, the proposal is either consummated or it is not, representing the second stage of the game. ${ }^{51}$ Using this framework, evaluating the U.S. and Canadian systems boils down to looking at what happens at each stage of the game. This is the object of the next three subsections.

\subsection{Acceptance and Confirmation}

One of the first studies to report confirmation rates for firms in Chapter 11 is Lopucki (1983), which examines a sample of 41 firms filing for Chapter 11 in the Western District of Missouri during the period 1979-80. ${ }^{52}$ According to Lopucki, 27 percent of the reorganization proposals were confirmed by the court. A more recent study by Flynn (1989) finds a significantly lower confirmation rate: ${ }^{53}$ about 17 percent of the Chapter 11 cases filed between 1979 and 1986 were confirmed by the bankruptcy court. Supporting Flynn, Jensen-Conklin (1992) finds a confirmation rate of 17 percent in a sample of 260 Chapter 11 cases filed in the Southern District of New York (Poughkeepsie) for the period 1980-89. ${ }^{54}$ Given that eleven of these confirmed proposals were liquidating proposals, the actual confirmation rate of reorganization plans is around 13 percent.

\footnotetext{
${ }^{50}$ J. Martel (1996a), supra note 49.

${ }^{51}$ Martel does not consider confirmation by the court an independent stage of the game. This is a weak assumption for Canada given the very high confirmation rate by the court.

${ }^{52}$ L. LoPucki (1983), supra note 5.

${ }^{53}$ E. Flynn, supra note 5.

${ }^{54}$ S. Jensen-Conklin, supra note 5.
} 
According to one view, the confirmation rate is low because Chapter 11 attracts too many small businesses. ${ }^{55}$ Eisenberg (1995) reports a Chapter 11 confirmation rate of 96 percent for firms with assets greater than $\$ 100$ million, a rate of 36 percent for firms with assets between $\$ 100$ million and $\$ 1$ million, and a rate of 20 percent for firms with assets lower than $\$ 1$ million. ${ }^{56}$ Flynn (1989) finds a confirmation rates of 7.4 percent for firms with assets less than $\$ 100,000,14$ percent for firms with assets between $\$ 100,000$ and $\$ 500,000$, 22 percent for firms with assets between $\$ 500,000$ and $\$ 1$ million, and 36 percent for firms with assets over $\$ 1$ million. ${ }^{57}$ LoPucki \& Withford (1991) find similar results: the 74 largest Chapter 11 cases filed during the period 1979-88 had a confirmation rate of around 90 percent. ${ }^{58}$ Weiss (1990) reports a confirmation rate of 86 percent from a sample of 37 New York and American Stock Exchange firms. ${ }^{59}$ Thus, U.S. data suggest that confirmation rates are significantly higher for larger firms. However, as noted above, the real confirmation rate is probably lower given the presence of a significant number of liquidating proposals.

Canadian data provide a very different picture. Martel (1994a) finds that 75 percent of the proposals are accepted by unsecured creditors. ${ }^{60}$ Among accepted proposals, 93 percent are confirmed by the bankruptcy court, implying a confirmation rate for all proposals of 70 percent $(75$ percent times 93 percent). These figures support earlier findings in Fisher \& Martel (1994b) who report an acceptance rate of 77 percent and that 96 percent of the accepted proposals are confirmed by the court, resulting in a confirmation rate of 74 percent. $^{61}$ Furthermore, as Table 3 shows, there seems to be no correlation between either acceptance or confirmation rates and firm size, contrary to U.S. evidence. Aggregating the data in Table 3 does not alter this conclusion: the confirmation rate for cases with less than $\$ 1$ million in assets is 72 percent, compared with 65 percent for cases with more than $\$ 1$ million in assets. The Canadian data also clearly show that the majority of

\footnotetext{
${ }^{55}$ T. Eisenberg \& S. Tagashira, supra note 4, D. Baird, supra note 3.

${ }^{56}$ T. Eisenberg, Creating an Effective Swedish Reconstruction Law, Report prepared for the Center for Business and Policy Studies, Stockholm, Sweden (1995).

${ }^{57}$ E. Flynn, supra note 5. Flynn suggests that these statistics should be used with some caution since the estimates of assets range are based on partial information.

${ }^{58}$ L. Lopucki \& W. Withford, Venue Choice and Forum Shopping in the Bankruptcy Reorganization of Large, Publicly-Held Companies, 139 Wisconsin Law Review (1991).

${ }^{59}$ L. Weiss, supra note 8

${ }^{60} \mathrm{~J}$. Martel (1994a), supra note 12.

${ }^{61}$ T. Fisher \& J. Martel, supra note 12.
} 
reorganizing firms are small. However, to the extent that there are problems with the Canadian reorganization system, they clearly are not caused by the presence of small firms with low acceptance and confirmation rates.

\subsection{Consummation Rate}

The second stage in reorganization comes down to whether a proposal is successful or 'consummated'. From a public policy perspective, it is important to examine what happens after confirmation in order to shed some light on the occurrence of filtering failure in reorganization. Until recently, few data were available on this topic. To our knowledge, the only study which examined this question was conducted by Jensen-Conklin (1992) who finds that 47 percent of confirmed proposals are "definitely" consummated. ${ }^{62}$

Using Canadian data, Fisher \& Martel (1994b) and Martel (1994a) arrive at a different conclusion. ${ }^{63}$ Fisher \& Martel find that 81 percent of the proposals accepted by unsecured creditors are consummated; Martel finds that 72 percent of accepted proposals are consummated. In addition, Martel shows that, as was the case for confirmation, there is no correlation between the consummation rate and the size of the firm. This can be seen from Table 3. Again, aggregating the data does not alter the main conclusion: the consummation rate for firms with less than $\$ 1$ million in assets is equal to 73 percent compared with 72 percent for firms with more than $\$ 1$ million in assets.

\subsection{Filtering Failure}

In recent years, the occurrence of filtering failure in bankruptcy has become a concern for an increasing number of economists and legal experts. From an efficiency perspective, the bankruptcy system ideally promotes the reorganization of viable firms and the elimination of non-viable firms. Filtering failures occur when the elimination process fails. As pointed out by Triantis (1996): "The merits of any bankruptcy system are determined by its effectiveness in correcting the inefficiencies that are signaled by the debtor's

\footnotetext{
${ }^{62} \mathrm{~S}$. Jensen-Conklin, supra note 5 . A proposal is considered to be definitely consummated if all payments promised to creditors in the plan are made. We also use this definition here as it corresponds to the definition used by Fisher \& Martel and Martel, supra note 12 and Martel supra note 49.

${ }^{63}$ T. Fisher \& J. Martel and J. Martel, supra note 12.
} 
financial distress." Triantis goes on to say: "... bankruptcy law is about enhancing the value of the firm's assets rather than preserving them." 64

The results reported in sections 5.1 and 5.2 raise serious concerns about the ability of Chapter 11 to filter firms in financial distress. Jensen-Conklin (1992) estimates that the probability of emerging from Chapter 11 as an ongoing entity is equal to 8.0 percent. ${ }^{65}$ Taking into account the presence of liquidating proposals, Jensen-Conklin concludes that a Chapter 11 debtor has a 6.5 percent chance of surviving as a going concern. Baird (1993) separates Chapter 11 firms into three groups. ${ }^{66}$ The first group comprises small to medium size businesses with assets under $\$ 500,000$ and represents more than two-thirds of the firms in Chapter 11. The second group comprises closelyheld firms of significant size. The third group comprises firms with publicly traded shares. Baird argues that the probability of surviving Chapter 11 is strongly correlated to firm size. For instance, fewer than 10 percent of firms in the small to medium size group emerge from Chapter 11 as going concerns. Baird concludes: "Chapter 11 is simply a station to eventual liquidation."

The results in Fisher \& Martel (1994b) and Martel (1994a) contrast significantly with the findings based on U.S. data. ${ }^{67}$ According to their results, the likelihood of Canadian firms surviving a reorganization under the BA lies between 63 percent and 55 percent. This means that Canadian firms are almost ten times more likely to survive reorganization than their U.S. counterparts. ${ }^{68}$

Fisher \& Martel (1995) provide an alternative measure of filtering failure by examining the possible incidence of Type I and Type II errors in the outcome of the creditors' vote on proposals. ${ }^{69}$ Following White (1994), a Type I error occurs when a non-viable firm survives Chapter 11 and a Type II error occurs when a viable firm is shut down in Chapter $7 .^{70}$ Using a sample of 348 reorganizing firms, 264 proposals were accepted and 84 rejected. ${ }^{71}$ Of

\footnotetext{
${ }^{64} \mathrm{G}$. Triantis, supra note 11.

${ }^{65}$ The probability of emerging from Chapter 11 as an ongoing entity is equal to the confirmation rate times the consummation rate (17 percent times 47 percent). S. JensenConklin, supra note 5 .

${ }^{66}$ D. Baird, supra note 3.

${ }^{67}$ T. Fisher \& J. Martel and J. Martel, supra note 12.

${ }^{68}$ The discussion on the reasons for such a difference is postponed to the section on "Implications for Chapter 11."

${ }^{69}$ T. Fisher \& J. Martel, supra note 12.

${ }^{70}$ Fisher \& Martel (1995) used the reverse the definitions for Type I and Type II errors.

${ }^{71}$ These data are a subsample of those in Martel (1994a). Incomplete files and the files
} 
the 264 accepted proposals, 66 subsequently enter liquidation.

It is not possible to determine the number of cases where a Type II error is committed, because it cannot be determined from the data which of the rejected plans were made by viable firms. However, the possible incidence of Type II errors can be determined given different levels of the incidence of Type I errors together with the fact that 84 plans are rejected. Table 4 presents possible scenarios for the incidence of Type I and Type II errors. ${ }^{72}$ The data show that the incidence of Type I errors is no less than 44 percent while the incidence of Type II errors is no more than 30 percent. According to White (1994) 'filtering failure' occurs in the bankruptcy process when Type I and II errors are committed by creditors. The overall incidence of filtering failure in the data is between 19 percent (66/348) and 43 percent $(150 / 348)$.

White (1994) proposes a theoretical model which brings out what can go wrong with Chapter 11. ${ }^{73}$ White shows that, in the presence of asymmetric information, it may be impossible to achieve full separation of viable and non-viable firms. As a result, pooling equilibria arise in which both types of firms offer the same reorganization contract. Martel (1996a) proposes a game theoretic model in which viable firms can use the structure of the reorganization contract in order to reduce the possibility of filtering failure. ${ }^{74}$ According to Martel, firms can signal their viability by using cash payments to creditors. ${ }^{75}$

Empirically, Martel finds the probability of success in reorganization increases with the proportion of short-term payments (within three to six months) to creditors, which is consistent with the informational role played

for which the outcome is unknown are deleted from the Martel (1994a) sample.

${ }^{72}$ Table 4 is determined as follows. If all 84 rejected plans are from non-viable firms, i.e., creditors always make the correct rejection decision, then the incidence of Type II errors is zero and the incidence of Type I errors is $66 /(66+84) \approx .440$, giving the first row. If 6 of the 84 rejected plans were from viable firms, then 78 rejected plans were made by non-viable firms, the incidence of Type I errors is $66 /(66+78) \approx .458$ and the incidence of Type II errors is $6 /(6+198) \approx .029$, giving the second row. The rest of the table is determined the same way.

${ }^{73} \mathrm{M}$. White, Corporate Bankruptcy as a Filtering Device: Chapter 11 Reorganizations and Out-of-Court Debt Restructurings, 10 J. of Law, Economics and Organization (1994)

\footnotetext{
${ }^{74}$ J. Martel, supra note 49.

${ }^{75}$ Martel also shows that, under certain conditions, pooling equilibria and filtering failures can also arise.
} 
by the structure of the reorganization contract. In addition, Martel finds that the probability of acceptance of a proposal increases with the perceived probability of success of the proposal by unsecured creditors. Using a different approach, Fisher \& Martel (1995) find a similar result. ${ }^{76}$ Based on their econometric analysis of the creditors' vote in reorganization, they conclude that the probability of acceptance of a proposal increases with the proportion of cash payments offered in the contract. Again, this result is consistent with the view that viable firms can use the structure of payments in reorganization to separate themselves from non-viable firms, thereby reducing the incidence of filtering failure.

\subsection{Expected Payment and the Best-Interests Test}

There are two additional key elements in evaluating the performance of the reorganization process. First, the speed at which creditors are reimbursed, and second, whether or not creditors expect a higher payment in reorganization than in liquidation. Jurists refer to this second element as the best-interests test while economists refer to it as the creditors' reorganization participation constraint.

According to Jensen-Conklin (1992), the duration of payments specified in U.S. plans ranges from immediately (i.e., upon confirmation) to approximately nine years after confirmation. ${ }^{77}$ In addition, 54 percent of the plans provide for complete repayment under the terms of the reorganization plan within one year of confirmation.

In Canada, according to Martel (1994a), the duration of payments varies from immediately to 10 years after confirmation. The average time for the payment of the reorganization payoff (i.e., the payment to creditors specified in the plan) is 14 months. ${ }^{78}$ The average grace period for the full sample is 3.7 months: 17 percent of the plans provide for no grace period, 30 percent for a one-month grace period, 29 percent for a three-month grace period, 14 percent for a six-month grace period, and 11 percent for a grace period in excess of six months from confirmation. Martel also shows that out of the total payment proposed to unsecured creditors, 9.7 percent is paid within strictly less than one month, 32 percent is paid within one month, 50 percent is paid within three months, 63 percent is paid within six months, and 78 percent

\footnotetext{
${ }^{76}$ T. Fisher \& J. Martel, supra note 12.

${ }^{77} \mathrm{~S}$. Jensen-Conklin, supra note 5.

${ }^{78} \mathrm{~J}$. Martel, supra note 12.
} 
is paid within 12 months of confirmation. Regression analysis also shows that there exists a trade-off between quicker payments and a higher proposed repayment. Similarly, a longer grace period is associated with a higher proposed repayment. ${ }^{79}$ These results clearly indicate that the Canadian reorganization process offers a quicker reimbursement of creditors's claims than Chapter 11.

Another important aspect in evaluating the performance of a reorganization system is whether or not unsecured creditors gain relative to liquidation. Theoretically, unsecured creditors will only approve a proposal if their participation constraint is satisfied, that is if they gain more, in expected value terms, in reorganization than in liquidation. ${ }^{80}$ In judicial terms, the analog to the participation constraint is the best-interests test. Compliance with the best-interests test is a necessary condition for court approval under the U.S. Bankruptcy Code. ${ }^{81}$ The Canadian BA makes no mention of compliance with the best-interests test, but it does allow the court to reject proposals that are not to the benefit of the general body of creditors. ${ }^{82}$

Surprisingly, there exists no evidence of compliance with the best-interests test in the U.S. or Canada. The only available evidence is reported by the Eisenberg \& Tagashira (1994) study of Japanese composition proceedings. ${ }^{83}$ In order to determine compliance with the best-interests test, the authors compare the discounted payment in reorganization and liquidation, taking into account the length of the plan, the grace period given to the debtor, and the time period required for liquidating the assets. They conclude that there is substantial compliance with the best-interests test for confirmed compositions.

Although there are no U.S. data to compare with, we feel that there are still lessons to be learned from examining the performance of the Canadian system in this area. To evaluate the extent to which proposals filed under the Canadian BA comply with the best-interests test, we adopt a slightly different approach than Eisenberg \& Tagashira. First, the reorganization payoff is measured as the sum of the periodic payments specified in the proposal,

\footnotetext{
${ }^{79}$ Eisenberg \& Tagashira find similar results for Japanese firms in composition. T. Eisenberg \& S. Tagashira, supra note 4.

${ }^{80} \mathrm{~J}$. Martel, supra note 49.

${ }^{81}$ Bankruptcy Code $\S 1129(\mathrm{a})(7)$.

${ }^{82}$ BA. $\S 59(2)$ [BIA $\left.§ 59(2)\right]$.

${ }^{83}$ T. Eisenberg \& S. Tagashira, supra note 4.
} 
discounted at a 10 percent annual rate. ${ }^{84}$ Second, a logit model of the probability of success of a proposal is estimated and the estimated coefficients are used to calculate a predicted probability of success for each proposal in the sample. ${ }^{85}$ Third, an expected discounted payoff in reorganization is calculated as the discounted payment times the predicted probability of success of the proposal. Next, an expected discounted liquidation payoff is calculated from the book value of the firms' assets, the estimated administration costs in liquidation and the mean time for repayment in liquidation. ${ }^{86}$

Table 5 reports the estimated mean values for the reorganization payoff, the discounted reorganization payoff, the probability of success of the proposal, the expected payment in reorganization, the discounted liquidation payoff, the surplus in reorganization over liquidation and the percentage of proposals which fail the best-interests test. These variables are first calculated for the full sample of firms in the data set and then, for comparison, separately for accepted and rejected proposals. ${ }^{87}$ According to calculations for the full sample, the proposed reorganization payoff is equal to 37.97 cents for every dollar of claims. Taking into account the time factor and the probability of success of the proposals, unsecured creditors expect to receive 24.32 cents in reorganization while they only anticipate 2.6 cents from liquidation. This leaves creditors with a surplus of 21.70 cents in reorganization. Interestingly, only four percent of the proposals in the sample fail the best-interests test, a figure similar to the one reported by Eisenberg and Tagashira (1994). In comparing the subsamples of accepted and rejected proposals, the data show that the surplus to unsecured creditors in reorganization is larger for ac-

\footnotetext{
${ }^{84}$ We use a higher discount rate that Eisenberg \& Tagashira (1994) who use a 7 percent rate. Given the high risks associated with these firms, a 10 percent rate is not unreasonable. Monthly payments are discounted using a compounded monthly discount rate consistent with a 10 percent annual rate.

${ }^{85} \mathrm{~J}$. Martel, supra note 49.

${ }^{86}$ The gross liquidation value of assets is estimated using a ratio of market to book value of 50 percent. Administration costs in liquidation are measured by category of book value of assets and estimated in proportion of the value of liquidated assets. They are equal to 62.9 percent for firms with assets lower than $\$ 100,000 ; 15.7$ percent for firms with assets between $\$ 100,000$ and $\$ 500,000 ; 9.5$ percent for firms with assets between $\$ 500,000$ and $\$ 1,000,000$; and 4.3 percent for firms with assets greater than $\$ 1,000,000$. The net liquidation value of assets is delayed by 2.24 years, which is the mean period of time in liquidation and discounted at a 10 percent rate. See J. Martel supra note 12.

${ }^{87}$ The full sample comprises 303 proposals for which all the relevant information is available. There are 235 accepted and 68 rejected proposals.
} 
cepted than for rejected proposals. Also, compliance with the best-interests test is higher for the subsample of accepted proposals. Overall, the data show that there is substantial compliance with the best-interests for proposals under the Canadian BA and there are gains for unsecured creditors in reorganization.

\subsection{Administrative costs}

An fundamental criticism of the formal bankruptcy mechanism is its high cost. ${ }^{88}$ There have been numerous studies in the U.S. that try to measure the size of bankruptcy costs. Warner (1977) finds that, on average, administrative costs amount to 5.3 percent of market value debt and equity at the time of bankruptcy for 11 railroad companies filing for bankruptcy during 1933-55. ${ }^{89}$ Similarly, Altman (1984) finds the ratio of administrative costs to asset market value of 6.0 percent in a sample of 18 manufacturers and retailers. ${ }^{90}$ White (1983) finds that administrative costs are 16 percent of the book value of liabilities at the time of filing for 96 firms filing for reorganization under the U.S. Bankruptcy Act (prior to 1979). ${ }^{91}$ Weiss (1990) estimates that bankruptcy costs amount to 21 percent of the market value of equity at the time of filing. ${ }^{92}$ But Weiss also finds that bankruptcy costs amount to only 3.1 percent of the sum of the book value of debt and market value equity and to only 2.8 percent of the book value of assets. Similarly, Betker (1995) finds a ratio of direct costs to assets of 3.9 percent for 75 Chapter 11 cases. ${ }^{93}$

From a sample of 393 firms in Canada, Martel (1994a) estimates that, at the time of filing, administrative costs amount to 4.3 percent of the book value of debt, 23 percent of the book value of assets, and 13 percent of the to-

\footnotetext{
${ }^{88}$ Bankruptcy costs can be divided into two components: direct and indirect costs. Given the absence of Canadian evidence on indirect bankruptcy costs, this study concentrates on direct costs.

${ }^{89}$ J. Warner, Bankruptcy Costs: Some Evidence, Journal of Finance 32 (1977).

${ }^{90}$ E. Altman, A Further Empirical Examination of the Bankruptcy Cost Question, 39 Journal of Finance (1984).

${ }^{91}$ M. White, Bankruptcy Costs and the New Bankruptcy Code, Journal of Finance 38 (1983).

${ }^{92}$ L. Weiss, supra note 8.

${ }^{93}$ B. Betker, The Administrative Costs of Debt Restructuring, Working Paper, Max. M. Fisher College of Business, Ohio State University (1995).
} 
tal payment to creditors under the proposal. ${ }^{94}$ Fisher \& Martel (1994b) find a mean ratio of administrative costs to assets of 22 percent and to total payment to creditors of 12 percent, which are very close to Martel's numbers. ${ }^{95}$ These values are higher than those reported by Ang, Chua \& McConnell (1982), White (1983), and White (1984) who report a mean ratio of administrative costs to total payment to creditors of 7.5 percent, 6.0 percent, and 3.0 percent respectively. ${ }^{96}$

The difference in the relative size of administrative costs between Canada and the U.S. is somewhat paradoxical. As indicated above, reorganization in Canada is accomplished much more quickly than in the U.S. Moreover, the daily cost of reorganization is lower in Canada. Martel (1994a) estimates that each extra day in reorganization raises total administrative costs by roughly \$24. Fisher \& Martel (1994b) find an even lower figure: each extra day adds about $\$ 8$ to the administrative cost of reorganization. ${ }^{97}$ These variable cost figure are significantly lower than those reported by White (1981) for the U.S., who finds that an extra month in reorganization raises administrative costs by $\$ 2,240$, or roughly $\$ 75$ a day. Thus, the variable costs of reorganization in Canada, i.e., the number of days in reorganization times the daily cost, are lower than the variable costs in the U.S., which, everything else equal, would imply lower administrative costs in Canada. However, the ratio of administrative costs to total payments to creditors is higher in Canada. We propose some tentative explanations.

One explanation lies in the fixed, as opposed to the variable, costs of reorganization. Unlike most U.S. studies, which examine large firms, Canadian studies are based on relatively small firms. When combined with the finding that there is a large fixed cost component in administrative costs, it is possible that the apparently high administration costs in Canada are simply due to the relatively large number of small firms reorganizing in Canada. In other words, if we could control for differences in firm size between the U.S. and Canadian data sets, the differences in administrative costs might be much smaller. Regressing administrative costs on assets, Martel (1994a)

\footnotetext{
${ }^{94}$ The total payment to creditors is the sum of secured claims and preferred claims plus the proposed return on the dollar to unsecured creditors times unsecured claims. J. Martel, supra note 12.

${ }^{95}$ T. Fisher \& J. Martel, supra note 12.

${ }^{96}$ J. Ang, J. Chua \& J. McConnell, The Administrative Costs of Corporate Bankruptcy: A Note, Journal of Finance 37 (1982); M. White, supra note 91; M. White, supra note 10.

${ }^{97}$ T. Fisher \& J. Martel, supra note 12.
} 
estimates that the fixed costs component in reorganization is approximately equal to $\$ 23,000$ and is significantly different from zero at the one percent level. ${ }^{98}$ This contrasts with Betker (1995) who estimates that the fixed costs component in Chapter 11 reorganization is not significantly different than zero. ${ }^{99}$

The higher administrative costs in Canada can also be explained in part by the presence of a trustee during proceedings. A necessary condition for the commencement of reorganization proceedings in Canada is that the debtor file a copy of the proposal with a trustee. ${ }^{100}$ Therefore, a trustee is always present the reorganization of a Canadian firm. According to Fisher \& Martel (1994b) and Martel (1994a), trustees' fees amount to 75-80 percent of the administrative costs of reorganization. ${ }^{101}$ In contrast, trustees are seldom present in U.S. reorganization proceedings. LoPucki (1983) reports the nomination of a trustee in only 5 of the 48 cases examined. ${ }^{102}$ Jensen-Conklin (1992) reports no cases in which a trustee was appointed. ${ }^{103}$

It is clear from the data that the time spent in reorganization is a determinant of direct bankruptcy costs. However, for the purpose of this study, time in reorganization is considered separately below.

\subsection{Time in Reorganization}

Another important element measuring the performance of the reorganization process is the amount of time spent by firms in reorganization. As pointed out by LoPucki (1993), reorganization can only be effective when cases move quickly. ${ }^{104}$ In addition, Bermant, Lombard \& Wiggins (1991) show that, although Chapter 11 cases represented only 2.5 percent of all filings under the Code in 1989, they required approximately 37 percent of all judicial effort. ${ }^{105}$

The length of the reorganization process has been examined by many studies in the U.S. and the findings vary significantly. The time in reor-

\footnotetext{
${ }^{98} \mathrm{~J}$. Martel, supra note 12.

${ }^{99}$ B. Betker, supra note 93

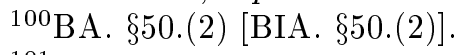

${ }^{101}$ T. Fisher \& J. Martel, supra note 12; J. Martel, supra note 12.

${ }^{102}$ L. LoPucki, supra note 5

${ }^{103} \mathrm{~S}$. Jensen-Conklin, supra note 5.

${ }^{104}$ L. LoPucki, supra note 4.

${ }^{105}$ G. Bermant, A. Lombard and E. Wiggin, supra note 6.
} 
ganization is defined in these studies as the time between the filing of the proposal and confirmation by the bankruptcy court. Based on a sample of 26 confirmed plans under the Bankruptcy Code, White (1984) estimates the average time period between filing and confirmation at 17 months. ${ }^{106}$ From a sample of 30 firms which emerged from Chapter 11 during the period 1970-84, Franks \& Torous (1989) estimate that the average time spent in Chapter 11 is about 44 months. ${ }^{107}$ Franks \& Torous (1994) estimate a mean time in reorganization of about 30 months from a sample of 37 firms which filed for Chapter 11 over the period 1983-88. ${ }^{108}$ Flynn finds a mean time of 25 months and that 18 percent of confirmations happen less than one year after filing, 43 percent between one and two years from filing, 22 percent between two and three years, and 17 percent after more than three years from filing. ${ }^{109}$ These results are similar to Altman (1993) who examines a sample of 284 Chapter 11 cases for the period 1979-91. ${ }^{110}$ According to Altman, the mean time in reorganization is equal to 21 months, with 31 percent of the plans being confirmed in less than a year from filing, 37 percent between one and two years, 19 percent between two and three years, and 13 percent after more than three years from filing. Gilson, John \& Lang (1990), examine a sample of 89 Chapter 11 cases and find a mean time in reorganization of 20 months. ${ }^{111}$ Lastly, Jensen-Conklin (1992) reports a mean time of 22 months, Weiss (1992) finds a mean time of 30 months for 37 cases in the 1979-86 period, and Daigle \& Maloney (1994) report a mean time of 21 months from a sample of 56 firms. ${ }^{12}$

Although Canadian studies do not measure the time between filing and confirmation, they do measure the time period between filing and voting by unsecured creditors. Everything else being equal, this period is shorter than the filing-to-confirmation measure used in U.S. studies. However, as we will

\footnotetext{
${ }^{106} \mathrm{M}$. White, supra note 10.

${ }^{107}$ J. Franks \& W. Torous, supra note 9.

${ }^{108}$ J. Franks \& W. Torous, A Comparison of Financial Recontracting in Distress Exchanges and Chapter 11 Reorganizations, 35 Journal of Financial Economics (1994).

${ }^{109}$ E. Flynn, supra note 5.

${ }^{110}$ E. Altman, Evaluating the Chapter 11 Bankruptcy-Reorganization Process, Columbia Business Law Review (1993).

${ }^{111}$ S. Gilson, K. John and L. Lang, Troubled Debt Restructurings: An Empirical Study of Private Reorganization of Firms in Default, 27 Journal of Financial Economics (1990).

${ }^{112}$ S. Jensen-Conklin, supra note 5, L. Weiss, Bankruptcy in Corporate America: Direct Costs and Enforcement of Claims, Journal of Legal Economics (1992); K. Daigle and M. Maloney, supra note 9.
} 
see, the difference between the two systems is so large that it cannot be explained simply by the difference in definitions. According to Fisher \& Martel (1994b), the average time between filing and voting on a reorganization plan under the BA is 51 days. Voting occurs in less than 30 days in roughly 90 percent of the proposals. Martel (1994a) finds similar results: the average time between filing and voting is 50 days, 60 percent of the proposals are voted on within 30 days of filing, 84 percent within 60 days, and 90 percent within 90 days. Typically, the time required for confirmation of a proposal by the court is between three weeks and one month, so let us suppose it is 30 days. ${ }^{113}$ This implies that the average time between filing and confirmation is around 80 days (50 days plus 30 days). Thus, U.S. firms take at least 6.4 and at most 17 times longer in judicial proceedings compared with their Canadian counterparts.

The two Canadian studies also report the total time spent by firms in reorganization, which is measured by the number of days between the voting date and the trustee's discharge date. Fisher \& Martel (1994b) and Martel (1994), respectively, find that firms spend about 45 months and 38 months in the reorganization process before being freed of all their obligations under their proposals. ${ }^{114}$

\subsection{Violation of Absolute Priority}

Another criticism of court-supervised reorganization is that it gives rise to violations of the absolute priority rule (APR). Technically, absolute priority is violated when lower-rank creditors receive payments while higher-rank creditors receive less than full repayment of their claims. In the U.S., many empirical studies confirm deviation from absolute priority. According to Franks \& Torous (1989), the fact that the debtor keeps control over the firm during the reorganization period gives them additional bargaining power in their negotiations with creditors. ${ }^{115}$ For instance, the debtor can intentionally delay the proceedings or invest in projects that could reduce the value of the creditors' claims. To avoid such actions, creditors may be willing to accept a reduction in their level of compensation to the benefit of the firm's equity-

\footnotetext{
${ }^{113}$ This is taken from discussions with bankruptcy practitioners. Section 58 of the BA (prior to 1992) provides for a minimum period of 14 days after the approval and before the court hearing.

${ }^{114}$ T. Fisher \& J. Martel and Martel, supra note 12.

${ }^{115}$ J. Franks \& W. Torous, supra note 9.
} 
holders. The authors find that the APR is violated in 78 percent of the cases $(21 / 27)$. In a subsequent study, Franks \& Torous (1994) find 80 percent of 37 cases examined violate the APR. ${ }^{116}$ The mean value of the deviation for the benefit of equity-holders is estimated at 2.3 percent of the total value of the restructured firm's securities. Similarly, Eberhart, Moore \& Roenfeldt (1990) find a deviation from the APR in 77 percent of the 30 cases examined in their study and a mean equity deviation of 7.5 percent of the value of restructured securities. ${ }^{117}$ In addition, the authors suggest that these deviations are anticipated by market participants and hence reflected in the price of equity.

Weiss (1990) finds that the APR is violated 78 percent of the time and that strict priority of unsecured claims is violated in almost three-quarters of the cases. ${ }^{118}$ White (1992) estimates that although equity-holders typically receive nothing when creditors receive less than 20 percent of the value of their original claims, they capture 79 cents for every additional dollar paid by the firm to creditors, the other 21 cents being captured by the creditors. ${ }^{119}$ Finally, Daigle \& Maloney (1994) find that equity deviations occurred in 40 of 46 firms which reorganized as a going concern and the mean amount of equity retained by the existing shareholders was 35 percent. ${ }^{120}$

In Canada, the importance of deviations from APR in reorganization is not well documented. However, Martel (1996b) argues that the APR between classes of creditors is likely to be respected in most reorganization cases under the BA. ${ }^{121}$ A proposal typically provides for the repayment of secured claims according to the existing contract or as renegotiated by the parties, translating into the full repayment of the original secured claims. Also, a proposal must explicitly provide for the full repayment of preferred claims in the order specified in section 136(1) of the Act before ordinary unsecured creditors can receive any payment. Therefore, Martel argues that there is likely to be little violation of the APR between classes of creditors.

${ }^{116}$ J. Franks \& W. Torous, supra note 108.

${ }^{117}$ A. Eberhart, W. Moore \& R. Roenfeldt, supra note 9.

${ }^{118}$ L. Weiss, supra note 8 . Weiss argues that expected deviations from the APR also affect the price of debt since creditors anticipate a wealth transfer to equity-holders. However, Weiss provides no empirical evidence on the magnitude of the effect.

${ }^{119}$ M. White, Measuring Deviations from Absolute Priority in Chapter 11 Bankruptcy, Journal of Legal Economics (July 1992).

${ }^{120}$ K. Daigle \& M. Maloney, supra note 9.

${ }^{121}$ J. Martel, Solutions au stress financiers: Un survol de la littérature, 72 Actualté Economique (1996). 
However, a systematic violation of the APR does occur when considering the treatment of equity-holders. Strictly speaking, equity-holders should lose all their control rights on the firm's assets if a class of creditors receives less than full payment of their claims, in which case equity and control of the firm is given to existing creditors. This reallocation of the firm's assets is natural in the case of firms with publicly traded shares, but it can represent an important problem in the case of firms with no shares traded or in cases of small businesses in which the managers are also the owners. For LoPucki \& Withford (1990), the APR is "virtually stood on its head" in such cases. Since the firm's future is highly dependent on the owner-manager's expertise, creditors are willing to waive part of the rights in the reorganized firms. ${ }^{122}$ Given that 97 percent of the firms in reorganization under the Canadian BA are firms with no publicly traded shares, the APR is likely to be violated in almost every case. ${ }^{123}$

\section{Lessons for Chapter 11}

The first lesson we learn from Canadian experience is that, contrary to common belief in the U.S., reorganization is not simply a station to eventual liquidation. Between 55 percent and 63 percent of Canadian firms reorganizing under the BA emerge as ongoing entities. It might be argued that this is due to the screening role played by the bankruptcy court in Canada. ${ }^{124} \mathrm{Sec}$ tion 50.4(11) of the Bankruptcy and Insolvency Act (post November 1992) allows the court to terminate a reorganization case early if it feels that the debtor has not acted in good faith, is not in a position to make a viable proposal that will be accepted by creditors, or if the creditors would be prejudiced by continuation of the case. But the BA (prior to November 1992) did not have a similar provision: the court had no power to terminate a reorganization case before the creditors' vote on the proposal. Thus, since the cases used in this study are from before 1992, one cannot attribute high survival rates to any screening role played by the bankruptcy court.

There is no support either for the claim that the problem with bankruptcy law is that too many small firms try to reorganize when they should be liquidated. Canadian data show no correlation between size and acceptance,

\footnotetext{
${ }^{122}$ L. Lopucki \& W. Withford, supra note 8.

${ }^{123} \mathrm{~J}$. Martel, supra note 12.

${ }^{124} \mathrm{G}$. Triantis, supra note 11 .
} 
confirmation, or consummation. Thus, the data provide little support for a recent suggestion to have two distinct reorganization procedures, one for small-to-medium size firms and one for large firms. ${ }^{125}$ A single reorganization procedure with enough flexibility to accommodate all types of firms is preferable to a dual system, which could give rise to strategic behavior. ${ }^{126}$

Another lesson that Chapter 11 could take from the Canadian reorganization process is the speed at which financial distress is resolved. In Canada, creditors vote on proposals, on average, less than 50 days after filing. Also, 90 percent of proposals come to a vote within three months. Furthermore, the average grace period is less than four months and creditors can expect to recover almost 80 percent of the proposed payment in the plan within a year of confirmation.

There are two potential explanations for the relatively quick resolution of reorganization in Canada. First, there is no exclusivity period for debtors and, more generally, there are greater incentives for parties to negotiate early in the process. Second, every reorganization case under the BA is supervised by a trustee. Although the pre-1992 BA did not specify explicit time limits for debtors to file proposals, in practice the system seems to have resulted in rapid votes on proposals. Fisher \& Martel (1995) find that the probability of acceptance of a proposal decreases with the time between the filing and voting on a proposal, suggesting implicit time constraints on reorganizing firms. ${ }^{127}$ And Martel (1996a) finds that 'holding' proposals have a 27 percent lower probability of being accepted than non-holding proposals, again suggesting implicit time limits in the system. ${ }^{128}$ The trustee discloses information to parties and oversees the process of reorganization. By disseminating information, the trustee stimulates negotiation between debtors and creditors and makes the process more transparent, thereby reducing the amount of time necessary to reach a settlement. ${ }^{129}$ The trustee can also bring experience and knowledge of the process to firms and creditors that have not previously

\footnotetext{
${ }^{125}$ L. LoPucki, supra note 4.

${ }^{126}$ In the conclusion, we argue that the existing Canadian system with two reorganization procedures should be reformed to allow only for one procedure.

${ }^{127}$ T. Fisher \& J. Martel, supra note 12.

${ }^{128} \mathrm{~J}$. Martel, supra note 49 . A holding proposal is an interim document filed by firms requiring more time to prepare a final proposal.

${ }^{129}$ In discussing the success of the Companies' Creditors Arrangement Act, Triantis (1996) makes the same argument: "the key to the success of this model in Canada is the disclosure of information during the reorganization process ..." G. Triantis, supra note 11 .
} 
taken part in a financial reorganization. Nonetheless, it must be noted that trustees are costly. Arguably, a more rapid solution to financial distress and a better separation of firms before reorganization will compensate for the increased bankruptcy costs associated with the presence of a trustee.

An obvious way to speed up Chapter 11 is to reduce the length of the exclusivity period. However, while feasible, this is unlikely to work very well in practice. LoPucki (1993) finds that the introduction of a pre-determined exclusivity period with the Bankruptcy Code resulted in firms exploiting the maximum time period to file proposals. ${ }^{130}$ Thus, whatever the length of the exclusivity period, it is likely that firms will make full use of the time. Moreover, firms can extend the exclusivity period by making an application to the court, which almost always approves extensions. Thus, in practice, management can take as long as they want before filing proposals. Another way to speed up the process would be to repeal the exclusivity period given to debtors, grant creditors permission to propose amendments to the original proposal filed by the debtor, and require the presence of trustee in every reorganization case. According to Canadian experience, we expect this system will converge to an equilibrium state in which the time firms take to file proposals will be determined by the behavior of all parties involved in the process, rather than just the firms alone. In addition, this system should minimize bankruptcy court intervention which would unduly delay the reorganization process. On the other hand, the court should have enough flexibility to dismiss cases where the debtor is not acting in good faith. ${ }^{131}$ As with the Canadian system, the nomination of a trustee and the possibility for creditors to propose amendments early in the reorganization process should accelerate the process and ensure a more efficient solution to financial distress.

In addition to these possible changes, we recommend that the 'cram down' provision be abolished from the U.S. Bankruptcy Code. ${ }^{132}$ Cram down allows the court to impose a plan on dissenting creditors after a process involving a lengthy and costly evaluation of the firm. From an efficiency point of view, cram down is difficult to justify. As pointed out by Aghion, Hart and Moore (1992), Chapter 11 gives considerable discretion to the bankruptcy court whereas efficiency requires leaving the firm's future in the hands of those

\footnotetext{
${ }^{130}$ L. LoPucki, supra note 4.

${ }^{131}$ Triantis (1996) refers to this as 'screens, gatekeepers, and guillotines'. G. Triantis, supra note 11.

${ }^{132}$ There are no cram down provisions in Canada.
} 
directly affected by the financial distress, namely the creditors. ${ }^{133}$ Thus, cram down essentially implies the court: (i) has better information than creditors on the future viability of the firm, or (ii) has the same information as creditors and estimates that the firm has a higher probability of success than dissenting creditors, or (iii) takes into account other considerations such as job losses, environmental damage, the rights of retirees to their pensions, and so on. ${ }^{134}$

The first possibility is difficult to believe given creditors have access to basically the same information as the court. The second possibility is more believable but is not desirable. As pointed out by Bebchuk (1988), reorganization represents, in essence, the sale of the firm to existing creditors who pay the firm with their existing claims and receive new interests in the reorganized firm. Since a firm's future should be decided by its owners, existing creditors at the time of reorganization should have the exclusive right to decide upon the firm's future. Extending this right to the court implies that there may be other considerations to the firm's reorganization. This is the third possibility raised above.

Broude (1994) argues that there may be good reasons to look at other considerations in reorganization. ${ }^{135}$ According to Broude, bankruptcy systems cannot be considered in isolation but must be addressed in a wider context, taking into account, for instance, social and environmental concerns as well as economic considerations. Thus, Broude argues that Chapter 11 could be used to deal with a range of consequences of financial failure like unemployment, loss of pension rights, environmental clean-up and so on. We totally disagree with this approach to bankruptcy law. It is our view that bankruptcy law should be aimed at finding an efficient solution to financial distress, either through the liquidation or the reorganization of a debtor's activities. It should not be used to solve problems that can be dealt with more effectively by other legislation. In addition, Broude overlooks an important problem created with his approach, namely that of moral hazard. Moral hazard arises when unobservable or hidden actions by agents acting in their own interest impose costs on others. ${ }^{136}$ In the present context, using bankruptcy

\footnotetext{
${ }^{133}$ P. Aghion, O. Hart \& J. Moore, supra note 2.

${ }^{134}$ See R. Broude, Some Comments on the Challenges of Commercial Reorganization in Insolvency: Why Chapter 11?, in Current Development in International Comparative Corporate Insolvency Law, ed. J. Ziegel, Clarendon Press, Oxford, 1994.

${ }^{135} \mathrm{R}$. Broude, supra note 134.

${ }^{136}$ P. Milgrom \& J. Roberts, Economics, Organization and Management, Prentice Hall,
} 
law to serve environmental goals may reduce incentives to firms to minimize the possibility of environmental damage and, hence, increase the likelihood of an accident. A similar argument could be made for unpaid wages. This is not to say that wage earners should not be insured, but rather that bankruptcy law is not the right tool to insure wage earners against financial distress. In general, using bankruptcy law to deal with problems that are not directly related to financial distress simply gives parties incentives to use the law for their own interests rather than for the interests of all creditors. Moreover, we agree with Aghion, Hart \& Moore (1992) who suggest that bankruptcy law should penalize managers adequately following financial distress. This is true for managers activities associated directly with bankruptcy as well as for indirect effects such as environmental damages, in which case managers could be held personally responsible for their actions. ${ }^{137}$

\section{Conclusion}

We have presented ample evidence of the relative efficiency of the Canadian reorganization procedure under the BA relative. The system promotes bargaining between debtors and creditors, puts the firm's future in the hands of creditors, offers a rapid resolution of financial problems, and a rapid repayment of creditors' claims. In addition, relative to liquidation, reorganization offers a net expected gain to creditors in over 95 percent of cases. Since the Canadian system shares many key aspects of the U.S. reorganization procedure, the evidence presented here suggests that there exist viable avenues to explore for reforming Chapter 11.

Canadian confirmation and consummation rates are significantly higher than those in the U.S., and there is no correlation between these rates and firm size. This offers no support for the view that "we need to be choosier about firms admitted to Chapter 11." 138 We believe that inefficiency in the U.S. reorganization process is due to the fact that the system gives the wrong incentives to participants and that the firm's future is not left exclusively to the creditors. Granting the bankruptcy court more discretion about who should and should not be admitted to Chapter 11 would simply reduce the efficiency of the system further. Thus, while we favor court intervention to

\footnotetext{
N.J. 1992.

${ }^{137}$ P. Aghion, O. Hart \& J. Moore, supra note 2.

${ }^{138}$ T. Eisenberg \& S. Tagashira, supra note 4.
} 
dismiss inadmissible cases, we believe that, in most reorganizations, the final decision should be in the hands of creditors. Moreover, creditors should be allowed to express their decision soon after the filing of a plan.

We claim that the Canadian reorganization procedure in the BA prior to the 1992 reform is a viable model for reforming Chapter 11. But the 1992 reform of the BA made it more similar to Chapter $11{ }^{139}$ From the standpoint of economic efficiency, therefore, we believe that the amendments to the Canadian BA represent a step backward. Analyzing the possible impact of the 1992 reform, Fisher \& Martel (1995) and Martel (1995) conclude that the reform should have only a slight impact on the acceptance rate of proposals. However, the new regime is expected to attract even more firms in the lower tail of the distribution of financially distressed firms. This will worsen the screening properties of the bankruptcy system and make the system more costly to the Canadian economy. Thus, to the extent that there are lessons to be learned from the Canadian experience, we suggest that the lessons should be learned from the pre-1992 Act and not the reformed Act.

\footnotetext{
${ }^{139}$ The main objective of the reform is to promote the use of financial reorganization in order to increase the chances of survival of firms in financial distress and to save jobs. The new Act also offers increased protection to wage earners in bankrupt firms. Fisher \& Martel and Martel, supra note 1.
} 


\section{Bibliography}

Aghion, P.; Hart, O.; and Moore, J. "The Economics of Bankruptcy Reform." Journal of Law, Economics and Organization 8 (1992): 523-546.

Altman, E. "A Further Empirical Examination of the Bankruptcy Costs Question." Journal of Finance 38 (1984): 1067-1089.

Altman, E. "Evaluating the Chapter 11 Bankruptcy Reorganization Process." Columbia Business Law Review (1993): 1-25.

Ang, J.; Chua, J.; and McConnell, J. "The Administrative Costs of Corporate Bankruptcy: A Note." Journal of Finance 37 (1982): 219-226.

Baird, D. "The Uneasy Case for Corporate Reorganization." Journal of Legal Studies 15 (1986): 127-147.

Baird, D. "A World Without Bankruptcy." Law and Contemporary Problems 50 (1987): 173-193.

Baird, D. "Revisiting Auctions in Chapter 11." Journal of Law and Economics, 36 (1993): 633-669.

Beardsley, J. "The New French Bankruptcy Statute." International Lawyer 19 (1985): 973-980.

Bebchuck, L. "A New Approach to Corporate Reorganizations." Harvard Law Review 101 (1988): 775-804.

Bermant, G.; Lombard, P.; and Wiggins, E. "A Day in the Life: The Federal Judicial Center's 1988-1989 Bankruptcy Court Time Study." American Bankruptcy Law Journal 65 (1991): 491-523.

Betker, B. "The Administrative Costs of Debt Restructurings."Working Paper, Max M. Fisher College of Business, Ohio State University (1995): $1-26$.

Bohémier, A. Faillite et Insolvabilité. Tome 1, Thémis, Université de Montréal (1992).

Bradley, M., and Rosenzweig, M. "The Untenable Case for Chapter 11." The Yale Law Journal, 101 (1992): 1043-1095.

Broude, R. "Some Comments on the Challenges of Commercial Reorganization in Insolvency: Why Chapter 11?" in Current Development in International Comparative Corporate Insolvency Law, ed. J. Ziegel, Clarendon Press, Oxford, 1994.

Casey, C.; McGee, V.; and Stickney, C. "Discriminating Between Reorganized and Liquidated Firms in Bankruptcy." The Accounting Review 61 (1986): 249-262. 
Daigle, K., and Maloney M. "Residual Claims in Bankruptcy: an Agency Theory Explanation." Journal of Law and Economics 37 (1994): 157192.

Duncan, L., and Honsberger, J. Bankruptcy in Canada. 3rd ed. Toronto: Canada Law Book, 1961.

Eberhart, A.; Moore, W.; and Roenfeldt R. "Security Pricing and Deviations from the Absolute Priority Rule in Bankruptcy Proceedings." Journal of Finance 45 (1990): 1457-1469.

Eisenberg, T. "Baseline Problems in Assessing Chapter 11." University of Toronto Law Journal 43 (1993): 633-677.

Eisenberg, T. and Tagashira, S. "Should We Abolish Chapter 11? The Evidence From Japan." Journal of Legal Studies 23 (1994): 111-157.

Eisenberg, T. "Creating an Effective Swedish Reconstruction Law." A Report Prepared for Center for Business and Policy Studies, Stockholm, Sweden (1995): 1-79.

Fisher, T., and Martel, J. "Will the Bankruptcy Reforms Work? An Empirical Analysis of Financial Reorganization in Canada." Canadian Public Policy 20 (1994): 265-277.

Fisher, T., and Martel, J. "Financial Reorganization in Canada." Canadian Business Economics 2 (1994): 54-66.

Fisher, T., and Martel, J. "The Creditors' Financial Reorganization Decision: New Evidence from Canadian Data." Journal of Law, Economics, and Organization 11 (1995): 112-126

Flynn, E. "Statistical Analysis of Chapter 11." The Administrative Office of the United States Courts, Bankruptcy Division (1989): 1-42.

Franks, J., and Torous, W. "An Empirical Investigation of U.S. Firms in Reorganization." Journal of Finance 44 (1989): 747-769.

Franks, J., and Torous, W. "A Comparison of Financial Recontracting in Distressed Exchanges and Chapter 11 Reorganizations." Journal of Financial Economics 35 (1994): 349-370.

Gilson, S.; John, K.; and Lang, L. "Troubled Debt Restructurings: An Empirical Study of Private Reorganization of Firms in Default." Journal of Financial Economics 27 (1990): 315-353.

Government of Canada. "Bankruptcy Act." R.S.C. 1985, c. B.3.

Government of Canada. "An Act to Facilitate Compromises and Arrangements Between Companies and Their Creditors." R.S.C. 1985, c. C.36.

Government of Canada. "An Act to Amend the Bankruptcy Act and to Amend the Income Tax Act in Consequence Thereof." (Bill C-22.) S.C. 
1992, c. 27.

Jackson, T. The Logic and Limits of Bankruptcy Law. Cambridge, Mass.: Harvard University Press, 1986.

Jensen-Conklin, S. "Do Confirmed Chapter 11 Plans Consummate? The Results of a Study and Analysis of the Law." Commercial Law Journal 97 (1992): 297-331.

Leonard, B. Guide to Commercial Insolvency in Canada. Toronto: Butterworths, 1988.

LoPucki, L. "The Debtor in Full Control-Systems Failure under Chapter 11 of the Bankruptcy Code?" American Bankruptcy Law Journal 57 (1983): 247-273.

LoPucki, L. "The Trouble with Chapter 11." Wisconsin Law Review 11 (1993): 729-760

LoPucki, L., and Triantis G. "A Systems Approach to Comparing U.S. and Canadian Reorganization of Financially Distressed Companies." Harvard International Law Journal 35 (1994): 267-343.

LoPucki, L., and Withford W. "Bargaining Over Equity's Share in the Bankruptcy Reorganization of Large, Publicly Held Companies." University of Pennsylvania Law Review 139 (1990): 124-196.

LoPucki, L., and Withford W. "Venue Choice and Forum Shopping in the Bankruptcy Reorganization of Large, Publicly-Held Companies." Wisconsin Law Review 11 (1991): 11-63.

Martel, J. "Commercial Bankruptcy and Financial Reorganization in Canada." Working Paper 94c-2, CIRANO (1994): 1-38.

Martel, J. "More on the Impact of Bankruptcy Reform in Canada." Working Paper No. 94s-17, CIRANO (1994): 1-17.

Martel, J. "Signaling in Financial Reorganization: Theory and Evidence from Canada." Unpublished manuscript, CIRANO (1996): 1-48.

Martel, J. "Solutions au stress financier: Un survol de la littérature." Actualité Economique 72 (1996): 51-78. 51-78.

Mayrand, M. "The Background of Canadian Bankruptcy Law." In Policy Forum on the Bankruptcy Act, edited Frank Lewis. Kingston, Ont.: John Deutsch Institute for the Study of Economic Policy, Queen's University (1985): 1-2

Milgrom, P., and J. Roberts. Economics, Organization and Management. New Jersey: Prentice Hall, 1992.

Rasmussen, R. "Debtor's Choice: A Menu Approach to Corporate Bankruptcy." Texas Law Review 71 (1992): 51-121. 
Roe, M. "Bankruptcy and Debt: A New Model for Corporate Reorganization." Columbia Law Review 83 (1983): 527-602.

Triantis, G. "The Interplay of Liquidation and Reorganization in the Bankruptcy Systems of Canada and the U.S.: The Role of Screens, Gatekeepers and Guillotines." International Review of Law and Economics 16 (1996): 101-120.

Warner, J. "Bankruptcy Costs: Some Evidence." Journal of Finance 32 (1977): 337-348.

Webb, D. "An Economic Evaluation of Insolvency Procedures in the United Kingdom: Does the 1986 Insolvency Act Satisfy the Creditors' Bargain?" Oxford Economic Papers 43 (1991): 139-157.

Weiss, L. "Bankruptcy Resolution: Direct Costs and Violation of Priority of Claims." Journal of Financial Economics 27 (1990): 285-314.

Weiss, L. "Bankruptcy in Corporate America: Direct Costs and Enforcement of Claims." Journal of Legal Economics (1992): 79-94.

White, M. "Economics of Bankruptcy: Liquidation and Reorganization." Working Paper No. 239. New York: Solomon Brother Center for the Study of Financial Institutions, Graduate School of Business Administration, New York University (1981): 1-40.

White, M. "Bankruptcy Costs and the New Bankruptcy Code." Journal of Finance 38 (1983): 477-487.

White, M. "Bankruptcy, Liquidation and Reorganization." In Handbook of Modern Finance, edited by Dennis Logue. Boston: Warren, Gorham \& Lamont, 1984.

White, M. "The U.S. Experience with Bankruptcy Reform." In Policy Forum on the Bankruptcy Act, edited by Frank Lewis. Kingston, Ont.: John Deutsch Institute for the Study of Economic Policy, Queen's University (1985): 19-24.

White, M. "The Corporate Bankruptcy Decision." Journal of Economic Perspectives 3 (1989): 129-151.

White, M. "Measuring Deviations from Absolute Priority in Chapter 11 Bankruptcy." Journal of Legal Studies (1992): 71-78.

White, M. "Corporate Bankruptcy as a Filtering Device: Chapter 11 Reorganizations and Out-of-Court debt Restructurings." Journal of Law, Economics, and Organization 10 (1994): 268-295. 


\section{TABLE 1}

\section{Characteristics of Reorganizing Firms ${ }^{1}$}

\begin{tabular}{|c|c|c|c|c|c|}
\hline$\overline{\text { Variable }}$ & Mean & 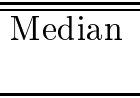 & $\begin{array}{l}\text { Standard } \\
\text { deviation }\end{array}$ & Minimum & Maximum \\
\hline \multicolumn{6}{|l|}{ Financial variables $^{2}$} \\
\hline Total assets & $2,453.3$ & 350.9 & $19,674.4$ & 0.0 & $385,770.7$ \\
\hline Total debts & $2,981.5$ & 783.9 & $15,876.0$ & 22.0 & $301,745.9$ \\
\hline Secured debts & $1,610.4$ & 201.3 & $12,248.1$ & 0.0 & $237,443.4$ \\
\hline Ordinary debts & $1,008.8$ & 438.8 & $2,025.6$ & 11.7 & $25,659.6$ \\
\hline Preferred debts & 111.5 & 23.7 & 322.0 & 0.0 & $4,318.7$ \\
\hline Crown debts & 76.1 & 15.1 & 204.7 & 0.0 & $2,424.7$ \\
\hline Contingent debts & 250.8 & 0.0 & $2,992.2$ & 0.0 & $56,880.0$ \\
\hline \multicolumn{6}{|l|}{ Financial ratios $^{3}$} \\
\hline Asset / debt & 58.3 & 55.3 & 37.2 & 0.0 & 229.0 \\
\hline Secured debt / asset ${ }^{4}$ & 54.9 & 56.4 & 35.7 & 0.0 & 100.0 \\
\hline Secured debt / debt & 32.0 & 30.8 & 25.1 & 0.0 & 96.3 \\
\hline Largest secured claim / debt & 23.7 & 21.5 & 19.9 & 0.0 & 91.5 \\
\hline Ordinary debt / debt & 59.5 & 58.2 & 26.4 & 1.0 & 100.0 \\
\hline Preferred debt / debt & 6.1 & 3.5 & 7.7 & 0.0 & 51.6 \\
\hline Crown debt / debt & 4.5 & 2.1 & 6.7 & 0.0 & 49.8 \\
\hline \multicolumn{6}{|l|}{ Creditor variables } \\
\hline Total number of creditors & 110.3 & 68.0 & 142.0 & 4.0 & $1,257.0$ \\
\hline Number of secured creditors & 3.4 & 2.0 & 17.1 & 0.0 & 331.0 \\
\hline Number of ordinary creditors & 86.5 & 59.0 & 98.2 & 2.0 & 834.0 \\
\hline Number of preferred creditors & 20.1 & 3.0 & 65.7 & 0.0 & 826.0 \\
\hline \multicolumn{6}{|l|}{ Creditor ratios ${ }^{3}$} \\
\hline Secured creditors / total creditors & 4.4 & 2.3 & 7.4 & 0.0 & 69.2 \\
\hline Ordinary creditors / total creditors & 84.4 & 89.0 & 14.6 & 15.3 & 100.0 \\
\hline Preferred creditors / total creditors & 10.8 & 5.4 & 13.5 & 0.0 & 75.3 \\
\hline
\end{tabular}

Notes:

1. The information contained in the table is based on 393 plans.

2. Measured in thousands of fourth quarter 1993 Canadian dollars normalized by the GDP deflator (Cansim Series number D20556).

3. Measured in percent.

4. In cases where the ratio exceeds $100 \%$ (including 14 firms with zero assets), it is set to $100 \%$. 
TABLE 2

Characteristics of the Reorganization Process

\begin{tabular}{|c|c|c|c|c|c|c|}
\hline Variables & 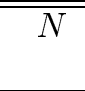 & Mean & Median & $\begin{array}{l}\text { Standard } \\
\text { deviation }\end{array}$ & "Minimum & Maximum \\
\hline \multicolumn{7}{|l|}{ Time variables $^{1}$} \\
\hline Time between filing and voting & 388 & 50.0 & 25.0 & 105.5 & 0.0 & $1,681.0$ \\
\hline Time in reorganization & 354 & $1,136.4$ & 965.0 & 756.6 & 70.0 & $5,057.0$ \\
\hline \multicolumn{7}{|l|}{ Unsecured creditors meeting variables } \\
\hline Number of amendments to the plan & 390 & 0.4 & 0.0 & 0.6 & 0.0 & 2.0 \\
\hline Number of creditors at the meeting & 330 & 30.9 & 19.0 & 36.8 & 1.0 & 269.0 \\
\hline$\%$ creditors at the meeting & 330 & 34.5 & 32.7 & 17.0 & 4.1 & 100.0 \\
\hline$\%$ creditors approving the plan & 330 & 84.4 & 90.9 & 20.2 & 0.0 & 100.0 \\
\hline$\%$ claims approving the plan & 330 & 80.6 & 29.8 & 29.8 & 0.0 & 100.0 \\
\hline \multicolumn{7}{|l|}{ Direct cost variables ${ }^{2}$} \\
\hline Administration costs & 344 & 46.3 & 20.0 & 92.2 & 1.7 & 897.0 \\
\hline Trustees fees & 340 & 27.8 & 13.6 & 46.3 & 0.6 & 399.4 \\
\hline \multicolumn{7}{|l|}{ Direct cost ratios ${ }^{3}$} \\
\hline Trustees fees / administration costs & 340 & 69.4 & 72.9 & 17.1 & 4.1 & 97.8 \\
\hline Administration costs / payments ${ }^{4}$ & 314 & 13.1 & 5.5 & 24.9 & 0.0 & 328.0 \\
\hline Administration costs / total assets & 344 & 4.8 & 2.9 & 5.3 & 0.0 & 34.3 \\
\hline Administration costs / total debts & 344 & 22.5 & 5.7 & 81.1 & 0.0 & $1,019.3$ \\
\hline
\end{tabular}

Notes:

1. Measured in days.

2. Measured in thousands of fourth quarter 1993 Canadian dollars normalized by the GDP deflator (Cansim Series number D20556).

3. Measured in percent. While all none of the minimum values are equal to zero, some are reported as zeros due to rounding.

4. Payments $=$ secured debts + preferred debts + (ordinary debts $\times$ payoff on ordinary claims). 
TABLE 3

Acceptance, Confirmation, and Consummation Rates by $\operatorname{Assets}^{1}$

\begin{tabular}{lccc}
\hline \hline Assets & $\begin{array}{c}\text { Acceptance } \\
\text { rate } \\
\text { (percent) }\end{array}$ & $\begin{array}{c}\text { Confirmation } \\
\text { rate } \\
\text { (percent) }\end{array}$ & $\begin{array}{c}\text { Consummation } \\
\text { rate }^{1} \\
\text { (percent) }\end{array}$ \\
\hline less than $\$ 100,000$ & 86.3 & 83.2 & 77.5 \\
$\$ 100,000$ to $\$ 500,000$ & 69.8 & 65.1 & 68.2 \\
$\$ 500,000$ to $\$ 1$ million & 68.9 & 67.2 & 71.4 \\
\$1 million to $\$ 5$ million & 72.6 & 63.1 & 70.7 \\
\$5 million to $\$ 10$ million & 86.7 & 80.0 & 76.9 \\
more than $\$ 10$ million & 66.7 & 58.3 & 71.4 \\
& & & 71.6 \\
less than $\$ 1$ million & 75.2 & 71.5 \\
more than $\$ 1$ million & 73.9 & 64.9 & 71.8 \\
All firms & 74.8 & 69.7 & 72.3 \\
\hline
\end{tabular}

TABLE 4

Possible Incidence of Type I And Type II ERrors in the CReditors' Decision

\begin{tabular}{cccc}
\hline \hline \multicolumn{2}{c}{ Number of rejected plans } & $\begin{array}{c}\text { Incidence of } \\
\text { Type I errors } \\
\text { (percent) }\end{array}$ & $\begin{array}{c}\text { Incidence of } \\
\text { Type II errors } \\
\text { (percent) }\end{array}$ \\
\hline from viable firms & from nonviable firms & 44.0 & 0.0 \\
\hline 0 & 84 & 45.8 & 2.9 \\
30 & 78 & 55.0 & 13.3 \\
54 & 54 & 68.8 & 21.4 \\
72 & 30 & 84.6 & 26.7 \\
84 & 12 & 100.0 & 29.8 \\
\hline
\end{tabular}

Notes:

1. The consummation rate measures the proportion of proposals accepted by creditors, confirmed by the bankruptcy court and for which all payments to creditors were made under the plan before the trustee is discharged. 
TABLE 5

Estimated Surplus ${ }^{1}$ And Best-Interests Test

\begin{tabular}{lccc}
\hline \hline & $\begin{array}{c}\text { Full } \\
\text { sample }\end{array}$ & $\begin{array}{c}\text { Accepted } \\
\text { plans }\end{array}$ & $\begin{array}{c}\text { Rejected } \\
\text { plans }\end{array}$ \\
\hline Payment & .3797 & .3822 & .3711 \\
Discounted payment & .3385 & .3393 & .3357 \\
Probability of success & .7509 & .7660 & .6987 \\
& & & \\
Expected discounted payment & .2432 & .2481 & .2265 \\
Discounted liquidation payment & .0260 & .0246 & .0316 \\
& & & \\
Reorganization surplus & .2170 & .2235 & .1949 \\
& & & \\
Plans failing best-interests test & & & \\
\end{tabular}

Notes:

1. Measured per dollar of claims.

2. Measured in percent. 


\title{
Liste des publications au CIRANO.
}

\author{
Cahiers CIRANO / CIRANO Papers (ISSN 1198-8169)
}

96c-1 Peut-on créer des emplois en réglementant le temps de travail ? / par Robert Lacroix

95c-2 Anomalies de marché et sélection des titres au Canada / par Richard Guay, Jean-François L'Her et Jean-Marc Suret

95c-1 La réglementation incitative / par Marcel Boyer

94c-3 L'importance relative des gouvernements : causes, conséquences et organisations alternative / par Claude Montmarquette

94c-2 Commercial Bankruptcy and Financial Reorganization in Canada / par Jocelyn Martel

94c-1 Faire ou faire faire : La perspective de l'économie des organisations / par Michel Patry

Série Scientifique / Scientific Series (ISSN 1198-8177)

96s-22 Should We Abolish Chapter 11 ? Evidence from Canada / Timothy C.G. Fisher, Jocelyn Martel

96s-21 Environmental Auditing in Management Systems and Public Policy / Bernard Sinclair-Desgagné, H. Landis Gabel

96s-20 Arbitrage-Based Pricing When Volatility Is Stochastic / Peter Bossaert, Eric Ghysels, Christian Gouriéroux

96s-19 Kernel Autocorrelogram for Time Deformed Processes / Eric Ghysels, Christian Gouriéroux, Joamna Jasiak

96s-18 A Semi-Parametric Factor Model for Interest Rates / Eric Ghysels, Serena Ng

96s-17 Recent Advances in Numerical Methods for Pricing Derivative Securities / Mark Broadie, Jérôme Detemple

96s-16 American Options on Dividend-Paying Assets / Mark Broadie, Jérôme Detemple

96s-15 Markov-Perfect Nash Equilibria in a Class of Resource Games / Gerhard Sorger

96s-14 Ex Ante Incentives and Ex Post Flexibility/Marcel Boyer et Jacques Robert

96s-13 Monitoring New Technological Developments in the Electricity Industry : An International Perspective / Louis A. Lefebvre, Élisabeth Lefebvre et Lise Préfontaine

96s-12 Model Error in Contingent Claim Models Dynamic Evaluation / Eric Jacquier et Robert Jarrow

96s-11 Mesures de la croissance de la productivité dans un cadre d'équilibre général : L'Économie du Québec entre 1978 et 1984 / Pierre Mohnen, Thijs ten Raa et Gilles Bourque

96s-10 The Efficiency of Collective Bargaining in Public Schools / Daniel S. Hosken et David N. Margolis

96s-09 Constant Consumption and the Economic Depreciation of Natural Capital : The NonAutonomous Case / John M. Hartwick et Ngo Van Long

96s-08 Upstream-Downstream Specialization by Integrated Firms in a Partially Integrated Industry / Gérard Gaudet, Ngo Van Long et Antoine Soubeyran

96s-07 Toward a Political Theory of Environmental Policy / Marcel Boyer et Jean-Jacques Laffont

* Vous pouvez consulter la liste complète des publications du CIRANO et les publications elles-mêmes sur notre site World Wide Web à l'adresse suivante :

http://www.cirano.umontreal.ca/publication/page1.html 